OPEN ACCESS

Edited by:

Jeremy Kiszka,

Florida International University,

United States

Reviewed by:

Tilen Genov,

Morigenos - Slovenian Marine

Mammal Society, Slovenia

Rob Harcourt

Macquarie University, Australia

${ }^{*}$ Correspondence:

Cormac G. Booth

cgb@smruconsulting.com

Specialty section:

This article was submitted to

Marine Megafauna,

a section of the journal

Frontiers in Marine Science

Received: 10 October 2019

Accepted: 13 February 2020

Published: 28 February 2020

Citation:

Booth CG, Sinclair RR and

Harwood J (2020) Methods for Monitoring for the Population Consequences of Disturbance in Marine Mammals: A Review.

Front. Mar. Sci. 7:115. doi: 10.3389/fmars.2020.00115

\section{Methods for Monitoring for the Population Consequences of Disturbance in Marine Mammals: A Review}

\author{
Cormac G. Booth ${ }^{1 *}$, Rachael R. Sinclair ${ }^{1}$ and John Harwood ${ }^{1,2}$ \\ ${ }^{1}$ SMRU Consulting, Scottish Oceans Institute, University of St Andrews, Fife, United Kingdom, ${ }^{2}$ Centre for Research into \\ Ecological \& Environmental Modelling, University of St Andrews, St Andrews, United Kingdom
}

Assessing the non-lethal effects of disturbance and their population-level consequences is a significant ecological and conservation challenge, because it requires extensive baseline knowledge of behavioral patterns, life-history and demography. However, for many marine mammal populations, this knowledge is currently lacking and it may take decades to fill the gaps. During this time, undetected population declines may occur. In this study we identify methods that can be used to monitor populations subject to disturbance and provide insights into the processes through which disturbance may affect them. To identify and address the knowledge gaps highlighted above, we reviewed the literature to identify suitable response variables and methods for monitoring these variables. We also used existing models of the population consequences of disturbance (PCoD) to identify demographic characteristics (e.g., the proportion of immature animals in the population, or the ratio of calves/pups to mature females) that may be strongly correlated with population status and therefore provide early warnings of future changes in abundance. These demographic characteristics can be monitored using established methods such as visual surveys combined with photogrammetry, and capture-recapture analysis. Individual health and physiological variables can also inform PCoD assessment and can be monitored using photogrammetry, remote tissue sampling, hands-on assessment and individual tracking. We then conducted a workshop to establish the relative utility and feasibility of all these approaches for different groups of marine mammal species. We describe how future marine mammal monitoring programs can be designed to inform population-level analysis.

Keywords: marine mammals, PCoD, monitoring, disturbance, populations, trends, demography

\section{INTRODUCTION}

Investigating the sublethal effects of disturbance and their consequences at a populationlevel remains a significant ecological and conservation challenge. It requires extensive baseline knowledge of behavioral patterns, life-history and demography. However, for most marine mammal populations, this knowledge is currently lacking and it could take many years to fill these gaps. During this time, undetected population declines 
may occur. Typically, marine mammal populations are monitored via surveys to determine their size or density. Whilst there are well established methods - such as line-transect surveys for cetaceans (e.g., Wade and Gerrodette, 1993) or telemetrycorrected haulout counts for pinnipeds (e.g., Thompson and Harwood, 1990) - for estimating the size of marine mammal populations, these are expensive, particularly in the case of cetacean populations. They also tend to provide imprecise estimates, because marine mammal populations are often spread over wide areas and individuals are often submerged, when they cannot be sighted. Consequently, monitoring programs based on these methods typically only have the power to detect large changes (Taylor et al., 2007; Jewell et al., 2012). Additionally, it may take many years before changes in vital rates manifest themselves as changes in population size if a species is long-lived. There may, therefore, be merit in monitoring demographic characteristics (such as the age- or stage-structure of the population) and indicators of individual health that can provide an early warning of population level effects and help to identify some of the drivers of changes (National Academies of Sciences Engineering and Medicine, 2017).

Working committees established by the National Research Council of the United States National Academies and the United States Office of Naval Research (National Research Council, 2005; New et al., 2014; National Academies of Sciences Engineering and Medicine, 2017) developed a conceptual model for assessing the population consequences of disturbance (PCoD). Those efforts led to a mathematical framework documented in Pirotta et al. (2018) (Figure 1). It describes how disturbance may impact both the behavior and physiology of an individual, and how changes in these characteristics may affect that individual's vital rates either directly (an acute effect) or indirectly via its health (a chronic effect). An individual's health integrates the potential effects of physiological and behavioral responses to stressors over a time scale that is longer than the duration of the responses themselves but shorter than the response time of vital rates. Changes in health indices can therefore provide an early indication of future reductions in vital rates, such as survival and reproduction. A key requirement for the implementation of the PCOD framework is therefore the ability to assess the health of individuals. A variety of health indices have been proposed, including allostatic load, energy stores, immune status, organ status, stress levels, contaminant burden, and parasite load (National Academies of Sciences Engineering and Medicine, 2017).

A number of studies have explored how changes in behavior (in response to disturbance) could affect energy reserves and the implications of this for fertility and survival in various marine mammal species including elephant seals (Mirounga spp.) (Schick et al., 2013b; New et al., 2014; Costa et al., 2016; Schwarz et al., 2016), bottlenose dolphins (Tursiops truncatus) (New et al., 2013a; Pirotta et al., 2015; Schwarz et al., 2016), North Atlantic right whales (Eubalaena glacialis) (Schick et al., 2013a; Rolland et al., 2016) and beaked whales (Family Ziphiidae) (New et al., 2013b).

The PCoD framework can be used to forecast the possible consequences of a range of disturbance scenarios. However, in data poor situations these forecasts have significant uncertainty associated with them, which can only be reduced by decades of research. Here, we review methods for monitoring such populations that can also provide insights into the processes through which disturbance may affect health and vital rates. This review provides both a retrospective and prospective view of how appropriate monitoring methods might be selected for a given marine mammal population. We also explore how the statistical power of a monitoring program to detect changes can be improved and identify contextual variables to aid interpretation of observed patterns.

We summarize the results of a literature review, and the outputs from an expert consultation. In addition, we explore the practicality of different methods for collecting appropriate datasets and use existing PCoD models to explore the potential of different demographic characteristics for providing an early warning of population decline. We conclude by describing how monitoring can inform future PCoD analysis of the effects of anthropogenic activities on marine mammal populations.

\section{MATERIALS AND METHODS}

\section{Literature Review and Workshop}

Although we reviewed the published literature spanning a wide range of monitoring methods, we do not provide an exhaustive review here. Instead, we focus on six methods that have been applied to monitor marine mammal populations. They are:

- hands-on assessment: capture-release, live stranding and necropsies,

- remote tissue sampling,

- capture-recapture approaches (that is, methods for which capture-recapture analyses can be applied to data once collected),

- photogrammetry,

- individual tracking,

- visual and acoustic surveys.

We categorized marine mammal species into the following groups: deep-diving cetaceans (including beluga and narwhal); baleen whales; coastal dolphins and porpoises (including river dolphins); oceanic dolphins; land-breeding pinnipeds; and ice-breeding pinnipeds. We did not consider sea otters, sirenians or polar bears.

The literature review process was supported by a workshop at which invited experts from a range of marine mammal research disciplines (Supplementary Table S1) were asked to assess and prioritize monitoring approaches for the different marine mammal species groups. Experts followed a lines of evidence (LoE) approach (e.g., Ross, 2000; Baruch et al., 2009; Amidan et al., 2015) to help identify the most suitable methods to monitor demographic characteristics and health variables (see Supplementary Material). Using the LoE approach, a set of response variables was identified, based on their "relative utility" (see Supplementary Material). Note, that the relative utility scores are non-linear and not directly comparable between methods for monitoring demography and individual health. The 


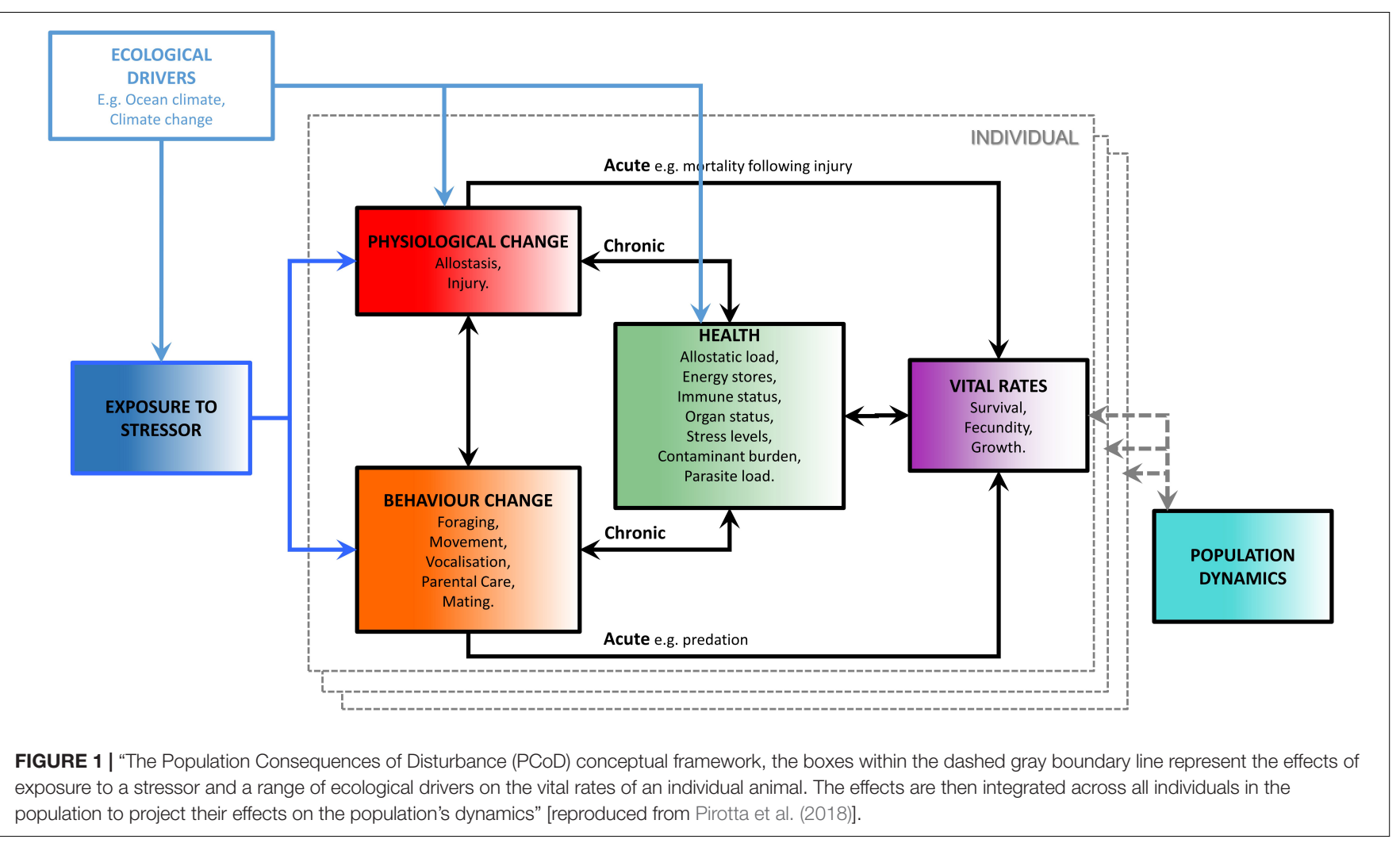

readiness of the available methodologies for monitoring these variables (i.e., their "feasibility") was also assessed. The feasibility and relative utility scores were plotted to identify approaches that were both feasible and had high utility.

\section{Demographic Characteristics That May Provide an Early Warning of Population Decline}

Population consequences of disturbance models developed using the outputs of earlier expert elicitations were used to evaluate whether the monitoring of demographic characteristics, rather than population size or density, may provide an early warning that a population is declining. In these elicitations, experts were asked to predict the potential effects of different levels of disturbance on the vital rates (individual survival and fertility) of a number of different marine mammal species. Here we focus on models for three species (harbor porpoise Phocoena phocoena, bottlenose dolphin and Blainville's beaked whale Mesoplodon densirostris) that have different life history strategies and that are exposed to different types of disturbance. The harbor porpoise and bottlenose dolphin population models were based on studies of the effects of noise associated with the construction of offshore wind farms in the North Sea (Harwood et al., 2014; King et al., 2015). The Blainville's beaked whale model was based on studies of the effects of sonars used in Navy exercises at the Atlantic Undersea Training and Evaluation Center (AUTEC) in the Bahamas (Moretti et al., 2014; Booth et al., 2016; Harwood and Booth, 2016). We investigated the sensitivity of the following demographic characteristics to changes in vital rates that might be caused by disturbance:
- the ratio of calves/pups to mature females;

- the proportion of immature animals in the population.

The first of these characteristics will be sensitive to changes in fertility and calf survival, the second will be sensitive to changes in fertility, calf survival and juvenile survival.

Details of the expert elicitation process we used can be found in Booth et al. (2016) and Donovan et al. (2016). In all the expert elicitations we asked the experts for their best estimates of the number of days of disturbance that would be required to have any effect on survival or fertility, the maximum likely effect of disturbance on these vital rates, and the number of days of disturbance that would be required to have this maximum effect. We also asked them for an estimate of the uncertainty they associated with these values. This information allowed us to construct a set of response functions of the form shown in King et al. (2015) for each expert. The opinions of all the experts were combined to provide a probability density surface for each function (e.g., see Figure 3 in King et al., 2015). In order to investigate the potential effects of a particular disturbance activity on a population, we obtained the views of many hundreds of "virtual" experts by sampling at random from these density surfaces. The functions from each virtual expert were incorporated into a stage-structured population model of the kind described in King et al. (2015) in order to investigate their implications for population dynamics.

For the simulated harbor porpoise populations, we investigated the effect of different levels of disturbance occurring over 10 years on a population of 10,000 animals. For bottlenose 
dolphins we investigated the effect of similar levels of disturbance on a smaller population (200 animals) because most coastal populations of this species are relatively small (Rosel et al., 2011; Cheney et al., 2018a). In both cases we examined the population consequences of the response functions predicted by 500 virtual experts, and compared the values of the two demographic characteristics at various times during the first 10 years with the ratio of the overall predicted decline in population size to the maximum decline in population size. Initially, we only accounted for variation between the opinions of the different virtual experts. However, environmental variation will also affect the value of the two demographic characteristics we chose to examine. We therefore re-ran the harbor porpoise simulations allowing survival and fertility to vary from year to year using experts' predictions of the level of environmental variability in these rates (see King et al., 2015). For the bottlenose dolphin population, we also took account of demographic stochasticity (the chance variation in survival and fertility between individuals which can affect the dynamics of small populations).

Beaked whales on Navy testing ranges are likely to be subject to the same pattern of disturbance over many years. For the Blainville's beaked whale example, we therefore examined the implications of 500 virtual experts' predictions of the effect of 44 days of disturbance each year (a typical pattern for United States Navy ranges, Moretti, 2019) for the long-term growth rate of a population. We then compared these long-term growth rates with the ratio of calves to mature females and the proportion of immature animals in the population as indicated by the stable age distribution associated with this long-term growth rate. We also calculated values for these demographic characteristics that would be obtained from samples of 1,000 or 100 individuals from a large population.

\section{RESULTS}

\section{Monitoring Methodologies for PCoD Hands-on Assessment: Capture-Release, Live Stranding and Necropsies}

Hands-on assessment makes use of animals that have been caught and then released, animals under managed care, and stranded or bycaught animals. The method received consistently high relative utility scores across all species groups for both demographic characteristics and health variables (see Supplementary Tables S2-S5 and Supplementary Figures S1, S2). However, the feasibility of using the method was considered to be low for deep-diving cetaceans, baleen whales and oceanic dolphins, except in situations where by-caught or harvested animals were available for study.

The demographic characteristics that can be estimated from hands-on assessment include age at sexual maturity and age at first pregnancy, sex ratio, and survival and pregnancy rate (see Supplementary Table S2). For example, whether or not an animal is pregnant can be assessed in a live animal using ultrasound, hormone analysis or physical examination of sex organs (e.g., Kjeld et al., 2006; Galatius et al., 2013; Kellar et al., 2013; Wells et al., 2014). Ultrasound has also been used to measure blubber thickness in stranded and bycaught small delphinids (Joblon et al., 2014) and live baleen whales, specifically North Atlantic right whales and southern right whales (Eubalaena australis) (Moore et al., 2001; Miller et al., 2011; Nousek-McGregor et al., 2013). Serum, urine and blubber samples can also provide a wide range of omics biomarkers, immune function markers and hormone measurements (see Mello and Oliveira, 2016 for a comprehensive review) (Supplementary Table S3). The age of individual animals can be estimated from growth layers in teeth (e.g., dolphin species, Hohn and Fernandez, 1999; pinnipeds, Blundell and Pendleton, 2008) or earplugs (e.g., baleen whales, Trumble et al., 2013), and from fatty acid concentration in blubber (e.g., odontocetes, Koopman et al., 2003; Herman et al., 2008).

Hands-on assessments of live animals can be performed as part of capture-release health assessments (see Hall et al., 2010) or individual-tracking studies, although this approach is typically limited to pinnipeds, small delphinid and porpoise species (Supplementary Tables S4, S5 and Supplementary Figures S1, S2). For example, bottlenose dolphins in Sarasota Bay, United States have been captured since the 1980's to conduct health assessments and to obtain demographic data such as sex ratio, age structure, pregnancy rates, survival rates and age at maturity (Wells and Scott, 1990; Wells et al., 2004). A range of health indicators can be obtained via these capture-release assessments (Schwacke et al., 2013; Schwacke and Wells, 2015; Unal et al., 2018). Serum samples and ultrasound have been used to assess physiological state and pregnancy status, respectively in pinnipeds captured for individual-tracking studies (e.g., Roletto, 1993; Mellish et al., 2004, 2006; Greig et al., 2010). Animals under managed care also provide opportunities for more controlled experimental studies (Champagne et al., 2017, 2018) though the applicability of the results to wild animals is poorly understood. Similar information can be collected from hands-on assessment of animals that strand live or dead. However, these animals may be subject to biases and not representative of the healthy population (described in Jones, 1981; Bilgmann et al., 2011; Peltier et al., 2012). In addition, deep-diving cetaceans and oceanic dolphins are less likely to be available for this kind of sampling than other marine mammal species groups because they wash ashore less frequently than coastal species. Even when a stranded carcass is available, its suitability to provide information on demographic characteristics and health variables will depend on its level of decomposition. The sample sizes obtained from hands-on assessments of stranded animals are usually small, but larger samples may be available from bycaught animals and animals harvested for subsistence or during culls.

\section{Remote Tissue Sampling}

Tissue samples may be collected remotely using biopsy darts, and from blows and feces (Piggott and Taylor, 2003; Hunt et al., 2013). Remote tissue sampling using biopsy darts was awarded a high feasibility and moderate utility scores for all species groups (Supplementary Tables S4, S5 and Supplementary Figures S1, S2). Sampling using blows and feces was awarded lower feasibility and utility scores. 
Samples obtained in these ways can provide information on a suite of health measures, including stress indicators (e.g., stress hormones, omics markers of chronic stress), levels of reproductive hormones, body condition indices and immune function markers. Remote sampling techniques do not require handling of the animal and therefore have applications for a wider range of marine mammal species. Biopsy samples of blubber can be analyzed to obtain data on sex ratios, reproductive hormones and wax/sterol esters or fatty acids to estimate the age/stage class of each individual (Supplementary Tables S2, S3). Remote sampling methods have been used to measure reproductive hormone levels in blubber samples from delphinid species (e.g., Kellar et al., 2009; Trego et al., 2013), baleen whales (e.g., bowhead whales, Kellar et al., 2013; humpback whales, Vu et al., 2015) and deep diving cetaceans such as sperm whale (Sinclair et al., 2015). Sampling the blow from respiring animals has been increasing in the recent decade (e.g., Hogg et al., 2009; Dunstan et al., 2012; Hunt et al., 2013; Thompson et al., 2014; Bennett et al., 2015; Apprill et al., 2017; Pirotta et al., 2017; Geoghegan et al., 2018; Nelsons et al., 2019). Along with fecal sampling it provides a non-invasive technique for monitoring the health of pinnipeds (Harvey, 1989; Fossi et al., 1997; Trites and Joy, 2005; Deagle and Tollit, 2007), killer whales (Hanson et al., 2010; Ford et al., 2011; Ayres et al., 2012) and baleen whale species (reviewed in Hunt et al., 2013). It is possible to obtain measures of a number of physiological markers from fecal samples. These include stress hormones, reproductive hormones, thyroid hormone metabolites (as indicators of nutritional stress), gut microflora (including parasite load), exposure to toxins, prey DNA and fecal hormone metabolites (used to assess acute vs. chronic stress markers) (Hunt et al., 2004, 2018, 2019). As with blow sampling, there is still a need for further work to validate these approaches and to understand how measurements obtained from blows and feces compare with those obtained via biopsy (Hunt et al., 2018).

\section{Capture-Recapture Analysis}

Capture-recapture analysis (also known as mark-recapture analysis) involves the initial "capture" and "marking" of individual animals, usually by taking a series of photographs that allow that individual to be identified from their markings and injuries (photo-identification or photo-ID). These individuals may be "recaptured" when subsequent photographs are compared to a catalog of known individuals. This method received high feasibility scores for all species groups except oceanic dolphins, and high utility scores for demographic characteristics.

Studies on coastal and oceanic dolphins have used the scratches and nicks on dorsal fins (e.g., bottlenose dolphins, Wells and Scott, 1990), or the dorsal fin shape and saddle patch markings of killer whales (e.g., Kuningas et al., 2014) to identify individuals. Capture-recapture techniques have been used extensively in coastal bottlenose dolphins to estimate a range of demographic characteristics (Hansen and Wells, 1996; Norman et al., 2004; De Wet, 2013; Schwacke et al., 2013; Fair et al., 2014). Studies on baleen whales have used fluke patterns (e.g., humpback whales, Gabriele et al., 2017), patterns of calluses and crenulations (e.g. southern right whales, Carroll et al., 2011) and patterns of pigmentation, scarring and barnacles (e.g., gray whales, Yakovlev and Tyurneva, 2005). Deep diving cetaceans can be identified using nicks and marks on the trailing edge of flukes (e.g., sperm whales, Matthews et al., 2001) and patterns of scars (e.g., beaked whales, Falcone et al., 2009; Rosso et al., 2011), and pinnipeds can be identified uniquely using their pelage patterns (e.g., harbor seals, Cordes and Thompson, 2015; ringed seals, Zhelezniakov et al., 2015). Other methods of capture have been employed. For example, genetic tagging (using genotyping) has been most extensively explored in baleen whales (Palsbøll et al., 1997; Lukacs and Burnham, 2005; Wiig et al., 2011). Capturerecapture analysis has also been used with telemetry data to estimate survival probabilities of first year gray seals (Halichoerus grypus) (McConnell et al., 2004). Non-permanent methods of marking have been used with pinnipeds, these include dyes or paints, flipper tags and shaving patches of fur. Dyes and paints are often used for shorter term studies, such as tracking gray seal pups from birth to first molt (e.g., Büche and Stubbings, 2016), but they are less effective for long-term studies as there is a high risk of mark loss which will affect the re-sighting rate.

Capture-recapture analysis has been used to assess population structure and demographic variables in a wide range of marine mammal species (e.g., Aguilar et al., 2013; Moretti et al., 2017; Schorr et al., 2017). For example, the Sarasota Dolphin Research Program have been conducting photo-ID studies of bottlenose dolphins since 1970 (Wells, 2014) to provide information on population size, survival rate, fecundity rate and age at maturity (e.g., Wells and Scott, 1990; Rosel et al., 2011; Bassos-Hull et al., 2013; Wells, 2014). Such baseline data provide a means to compare demographic characteristics before and after perturbation events, and to identify the early warnings of declines.

\section{Photogrammetry}

Photogrammetry and videogrammetry (henceforth collectively referred to as "photogrammetry") provide a non-invasive method for analyzing photographs to provide information on body shape, health and nutritional status (Durban et al., 2015). When images are combined with information on scale, they can be used to estimate morphometric characteristics (e.g., length, girth etc.) Such measurements can provide information on the age or stage class of an individual, provided a suitable growth curve or other calibration data are available, and on individual body condition. This method received high feasibility scores, and high to moderate utility scores for all species groups (Supplementary Figures S1, S2).

Photogrammetry has been used to measure size and body condition for sperm whales (Dawson et al., 1995), blue whales (e.g., Durban et al., 2016), North Atlantic and southern right whales (Pettis et al., 2004; Christiansen et al., 2018), humpback whales (e.g., Christiansen et al., 2016; Mason, 2017), gray whales (Bradford et al., 2012), killer whales (e.g., Fearnbach et al., 2015), common dolphins (e.g., Perryman and Lynn, 1993), spinner dolphins (Karczmarski et al., 2005), gray and harbor seals (e.g., Pomeroy et al., 2015), Weddell seals (Leptonychotes wedellii) (Ireland, 2004), Galapagos sea lions (Meise et al., 2014) and Hawaiian monk seals (McFadden et al., 2006). Its potential for 
identifying pregnancy state in large baleen whale species has also been investigated (Perryman and Lynn, 2002; Miller et al., 2011, 2012a). Fiori et al. (2017) provide a detailed review of its use in marine mammal research.

The simplest form of photogrammetry used in marine mammal surveys involves a single-camera deployed from a vessel, aircraft or land with a suitable scale indicator, such as a known size object or precisely calibrated camera lens (Dawson et al., 2017). The use of unmanned aerial systems or "drones" has become increasingly common and has facilitated significant advances in the field. However, there are concerns that it may cause short-term disturbance to some species (Fettermann et al., 2019). Single-camera photogrammetry is often conducted at the same time as marine mammal surveys.

For stereo-photogrammetry, simultaneous photos are taken from two cameras a known distance apart. This method does not require a scaling object to be present in the image. Parallellaser photogrammetry involves mounting dual lasers onto the camera system. The laser dots in the resulting photographs can be used as a scale in order to obtain morphometric measurements (e.g., Durban and Parsons, 2006). For example, the dorsal fin length of some dolphin species can be used as a predictor of total body length; therefore, if images are obtained of the dorsal fin and the two laser dots, the length of the dorsal fin can be measured from the images and the total body length can be estimated. This has been demonstrated in Hector's dolphins (Cephalorhynchus hectori) (Webster et al., 2010) and spinner dolphins (Stenella longirostris) (Karczmarski et al., 2005). In the Moray Firth, United Kingdom, the length of bottlenose dolphin calves has been shown to be significantly correlated with survival through the first winter (Cheney et al., 2018b). There is, therefore, the potential for body size measurements to provide an estimate of calf survival rates. Parallel-laser photogrammetry can also provide data on body condition if the images are taken from above to give both length and width measurements. Three-dimensional photogrammetry has been used to estimate dimensions, condition and mass for pinnipeds on land (e.g., Stellar sea lions, Waite et al., 2007; southern elephant seals, Postma et al., 2013). Obtaining photos from multiple angles for animals that are wholly or partially submerged is more challenging.

Photogrammetry has been widely used to provide information on individual health, particularly for North Atlantic and southern right whales (Pettis et al., 2004; Christiansen et al., 2018) and other baleen whale species (Burnett et al., 2019). Recent advances of this methodology include the use of three-dimensional volumetric models to allow estimation of mass (Beltran et al., 2018; Adamczak et al., 2019; Christiansen et al., 2019), and longitudinal studies to assess reproductive investment in calves (Christiansen et al., 2018).

Photogrammetry also allows a number of visible indicators of health to be recorded [reviewed by Hall et al. (2010)]. These include rake marks and epidermal lesions (Thompson and Hammond, 1992; Hughes-Hanks et al., 2005; Van Bressem et al., 2009), and the shape of the post-nuchal (Gryzbek, 2013; Reed et al., 2015) and scapular depressions (e.g., Bradford et al., 2012). Rolland et al. (2007) used a combination of information from visual indicators and fecal sampling (to assess parasite load) to provide a single health metric for individual North Atlantic right whales. This information was then analyzed in a Bayesian framework to explore the links between health metrics, vital rates and population status (Schick et al., 2013a; Rolland et al., 2016).

\section{Individual Tracking}

Telemetry has been used to track the movements of individual marine mammals over both short (Johnson and Tyack, 2003; Miller et al., 2012c; DeRuiter et al., 2013), intermediate (Mate et al., 2016) and longer time scales (Mate et al., 2000, 2007; Peterson et al., 2012; Hindell et al., 2016). Such approaches have been widely used for assessing baseline behavior and to study the responses of animals to disturbance sources. Telemetry studies have provided information on residency patterns and activity budgets in a wide range of species (e.g., McConnell et al., 2004; Aarts et al., 2008; Patterson et al., 2010; Laidre and Heide-Jorgensen, 2012; Mcclintock et al., 2012, McClintock et al., 2013). While demographic information can potentially be collected using this method (e.g., McConnell et al., 2004), it was considered to have low utility for monitoring demographic characteristics at present. However, it received a high score for feasibility for monitoring health in deep-diving cetaceans and seals. This is because the analysis of dive behavior - particularly "drift dives" (Biuw et al., 2003, 2007) - can provide information on the buoyancy of an individual that can be used as an index of body condition. This analysis has been used to derive a measure of body density in elephant seals (Aoki et al., 2011; Miller et al., 2012b; New et al., 2014), fur seals (Costa et al., 1989; Page et al., 2005) and northern bottlenose whales (Hyperoodon ampullatus) (Miller et al., 2016). Its use is currently being explored for humpback, blue and long-finned pilot whales (P. Miller pers. comm). In some cases it may also possible to correlate buoyancy with pregnancy (e.g., Crocker et al., 1997).

\section{Visual and Acoustic Surveys}

Visual and acoustic surveys are standard methodologies for estimating marine mammal density using vessel, aerial or land platforms (e.g., Buckland et al., 2001, 2004). However, visual surveys can also provide information on demographic characteristics, such as mother-calf ratios, which can be used to estimate birth rate (Kogi et al., 2004; Koski et al., 2008; Currey et al., 2009; Perryman et al., 2010)(see Supplementary Tables S2, S3).

Acoustic surveys of marine mammals are usually conducted using some form of Passive Acoustic Monitoring (PAM) (e.g., McDonald and Fox, 1999; Mellinger and Barlow, 2003; Mellinger et al., 2007, 2011; Marques et al., 2009; Mellinger and Heimlich, 2013) which relies on detecting the sounds produced by marine mammals. It is best developed for cetaceans but it has been used successfully for pinnipeds. Characterizing the vocalizations made by the species that are being surveyed is critical to the success of this approach (Supplementary Tables S4, S5 and Supplementary Figures S1, S2). PAM surveys are routinely conducted using towed hydrophones deployed from vessels (Barlow and Taylor, 2005; Gillespie et al., 2005, 2010; Barlow et al., 2013) and, more recently, from gliders and other 
autonomous mobile platforms (Baumgartner and Fratantoni, 2008; Klinck et al., 2012; Baumgartner et al., 2013). However, in these approaches the number of animals detected is often limited by the length of time that a suitable towing platform is available. Fixed PAM installations allow for cost-effective long-term monitoring over limited spatial extents and have been used to estimate the density of a number of cetacean species (Harris, 2012; Harris et al., 2013; Thomas et al., 2017; Carlén et al., 2018). These installations can generate significant sample sizes, and thereby increase the ability to detect trends (Gerrodette et al., 2011).

\section{Demographic Characteristics That May Provide an Early Warning of Population Decline}

Here we describe the outcomes of the PCoD model simulations described in the section "Materials and Methods."

\section{The Ratio of Calves to Mature Females}

Figure $\mathbf{2 A}$ shows the relationship between the maximum reduction in harbor porpoise population size recorded during each simulation and the ratio of calves to mature females in the third year of disturbance. Although there was a good correlation between the pairs of values, there are some clear outliers, where a large reduction in population size was not matched by a change in the ratio of calves to mature females. These outliers correspond to the opinions of a small number of virtual experts who predicted that disturbance would have a large effect on juvenile survival, but very little effect on fertility or calf survival. In addition, Figure $\mathbf{2 A}$ overestimates the power of this demographic characteristic to provide an early warning of population decline because it does not account for the effects of environmental variation, which will also affect the stage-structure of the population. Figure $\mathbf{3 A}$ shows the relationship between maximum population decline and the ratio of calves to mature females when environmental variation was included in the simulations. The predictive power is much reduced.

Figure $4 \mathrm{~A}$ shows the relationship for bottlenose dolphins between the maximum reduction in population size recorded in each simulation and the mean ratio of calves to mature females in the first 3 years of disturbance, including the effects of environmental variation. The mean ratio was used rather than the value from a single year because of the small population size and low fertility rate for bottlenose dolphins, which resulted in large variations in the predicted number of calves born each year. Although there is a clear correlation between the pairs of values, there is a much variability, with a wide range of values of the ratio corresponding to each reduction in population size.

In order to investigate the effectiveness of monitoring the ratio of calves to adult females for Blainville's beaked whales, we modeled a population with the same demographic rates as those observed by Claridge (2013) for an undisturbed population in the Bahamas. The effects of disturbance resulted in reductions of between $0 \%$ and $6 \%$ in the predicted population growth rate. The ratio of calves to mature female animals derived from the stable stage structure for each disturbed population was a highly reliable predictor of long-term population growth rate. However, these values are not presented here because, in practice, it would be impossible to estimate this demographic characteristic with the kind of precision that is provided by the stable stage structure. Instead, Figure 5Aa shows the relationship if estimates of the ratio of calves to mature females were based on sample of 1,000, and Figure 5C shows the relationship for a sample of 100 .

The Proportion of Immature Animals in the Population Figure 2B shows the relationship between the maximum reduction in population size and the proportion of immature animals in a harbor porpoise population after 5 years of disturbance. To allow time for the effects of disturbance on fertility and calf survival to influence this demographic characteristic, we chose a later date than that used for the ratio calves to mature female ratio (above). Figure $\mathbf{3 B}$ shows the same relationship when environmental stochasticity was included in the simulations. As with the ratio of calves to mature females, there were a large number of outliers from a simple relationship when there was no environmental stochasticity, and the addition of environmental stochasticity substantially increased the uncertainty associated with the relationship. Results for bottlenose dolphins (Figure 4B) were similar.

For Blainville's beaked whale, Figure 5 shows the relationships between population growth rate and the proportion of immature animals for samples of 1,000 individuals (Figure 5B) and 100 individuals (Figure 5D).

\section{Effectiveness for Monitoring}

We used the results of the simulations described above to evaluate the likely effectiveness of a monitoring program based on either the ratio of calves to mature females, or the proportion of immature animals. Specifically, we examined whether these demographic characteristics could be used to provide an early warning of a potential population reduction of $40 \%$ or more by the end of the period of disturbance.

It was not possible to identify an appropriate early warning threshold for the ratio of calves to mature females in year 3 of the harbor porpoise simulations that did not result in unacceptable numbers of false positives (simulations in which the ratio of calves to mature females fell below the threshold in year 3, but the maximum population decline was actually less than 40\%) or false negatives (simulations in which the population declined by $40 \%$ but the ratio of calves to mature females in year 3 was above the threshold). For example, although a ratio of calves to mature females of 0.25 resulted in relatively few $(21 \%)$ false positives, the false negative rate was $50 \%$. However, results using the proportion of immature animals in the population were more encouraging. For example, using a threshold of 0.2 for the proportion of immature animals in year 5 correctly identified $81 \%$ of all declines greater than $40 \%$, and had a false positive rate of only $10 \%$. 

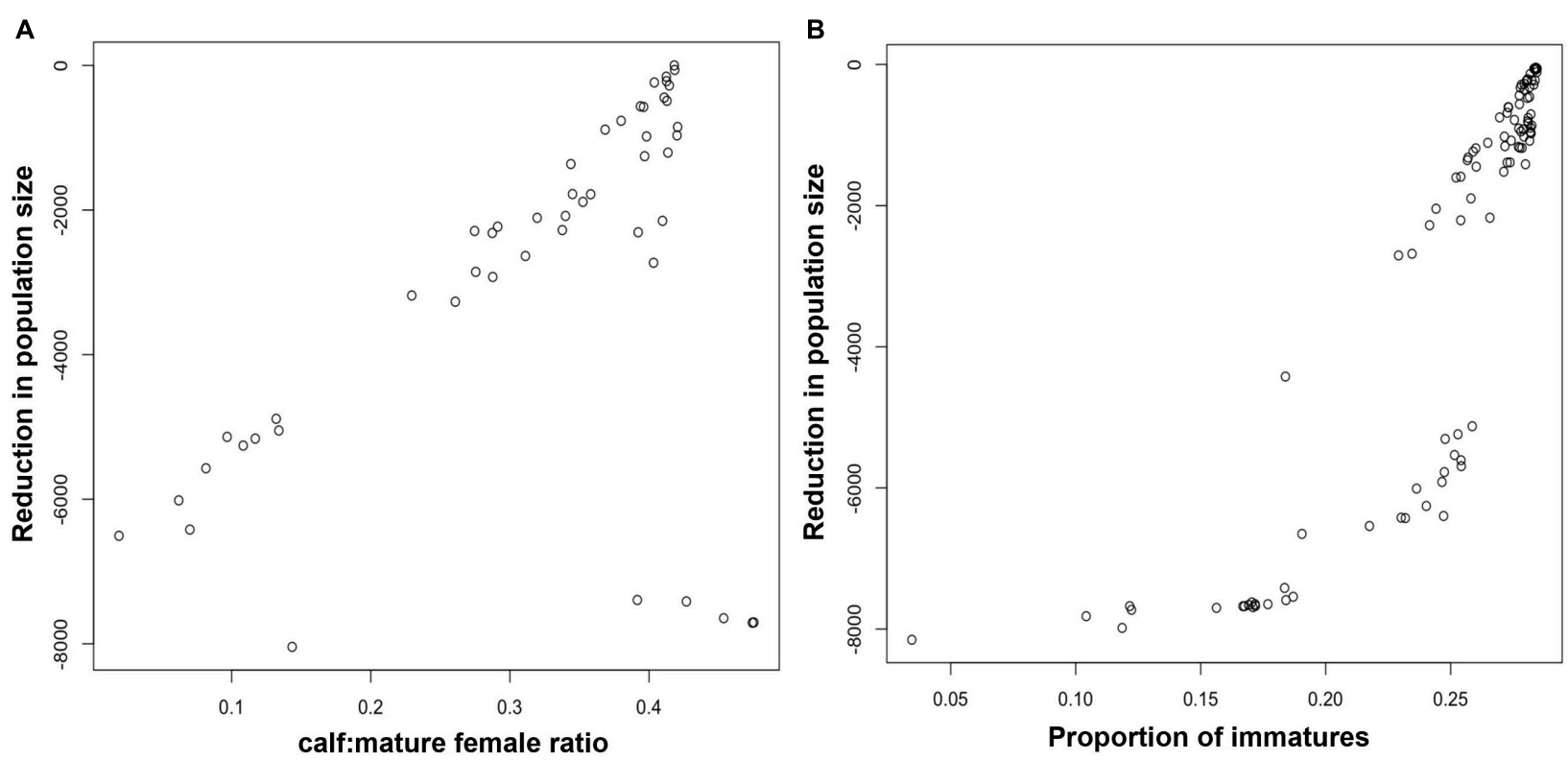

FIGURE 2 | Relationship between the maximum predicted reduction in harbor porpoise population size and (A) the ratio of calves to mature females in year 3 , and (B) the proportion of immature animals in year 5.
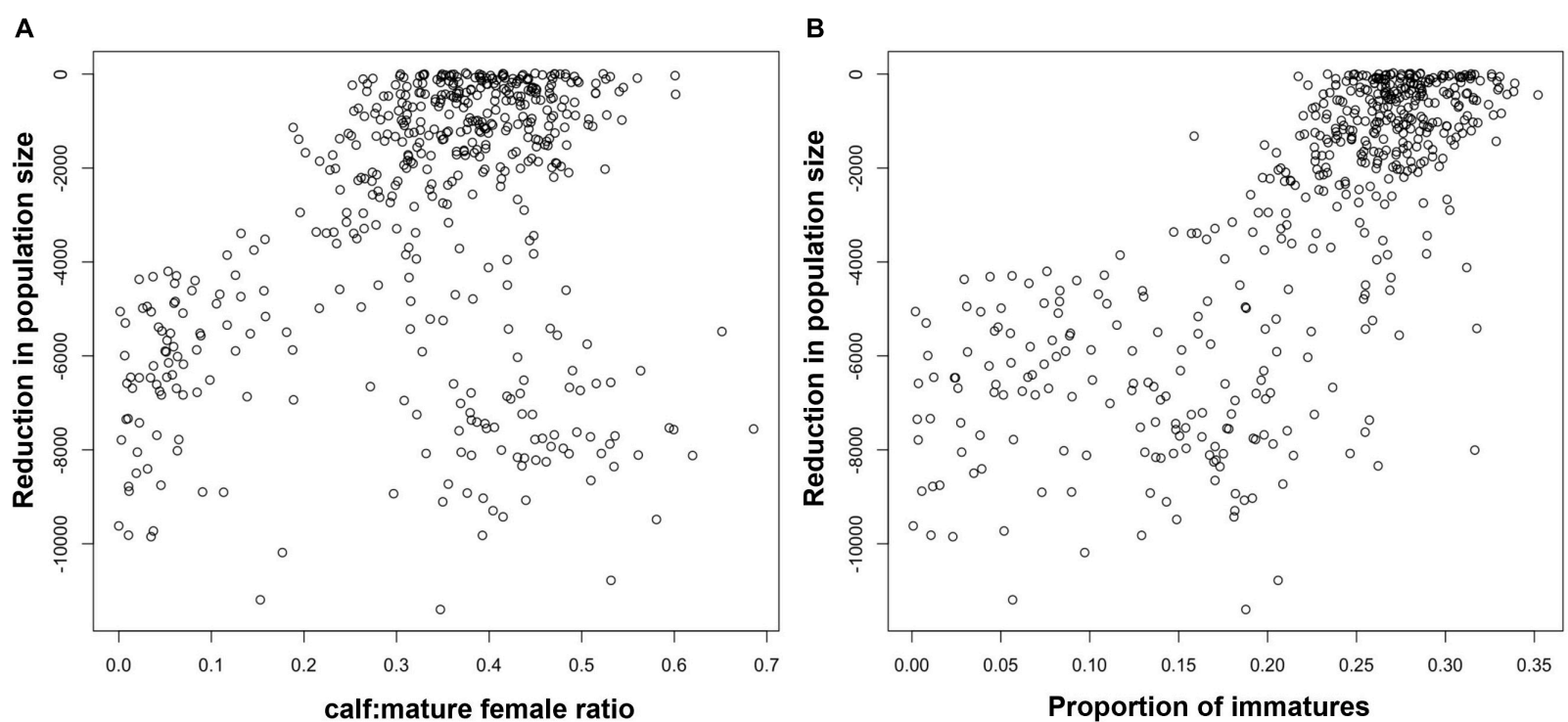

FIGURE 3 | Relationship between the maximum predicted reduction in harbor porpoise population size and (A) the ratio of calves to mature females in year 3 , (B) the proportion of immature animals in year 5 when environmental variation was included in the simulations.

Similar results were obtained for bottlenose dolphins: early warning thresholds that occurred in a high proportion of the simulations in which there was a population decline of at least $40 \%$ also had a high false positive rate $(45-50 \%)$.

In general, these results suggest that the ratio of calves to mature females may be problematic as an early warning indicator, but that the proportion of immature animals in the population may be a more robust indicator of a potential population reduction.
Results from the Blainville's beaked whale analysis were qualitatively similar. Although the proportion of immature animals in a sample of 1,000 animals appears to provide a good indicator of long-term population growth rate (Figure 5B), it is extremely unlikely that 1,000 animals can be classified from surveys on a regular basis, given the observed densities of this species. However, the proportion of immature animals in a sample of 100 individuals can provide a reliable indication that the population is declining: the proportion of immatures in all 

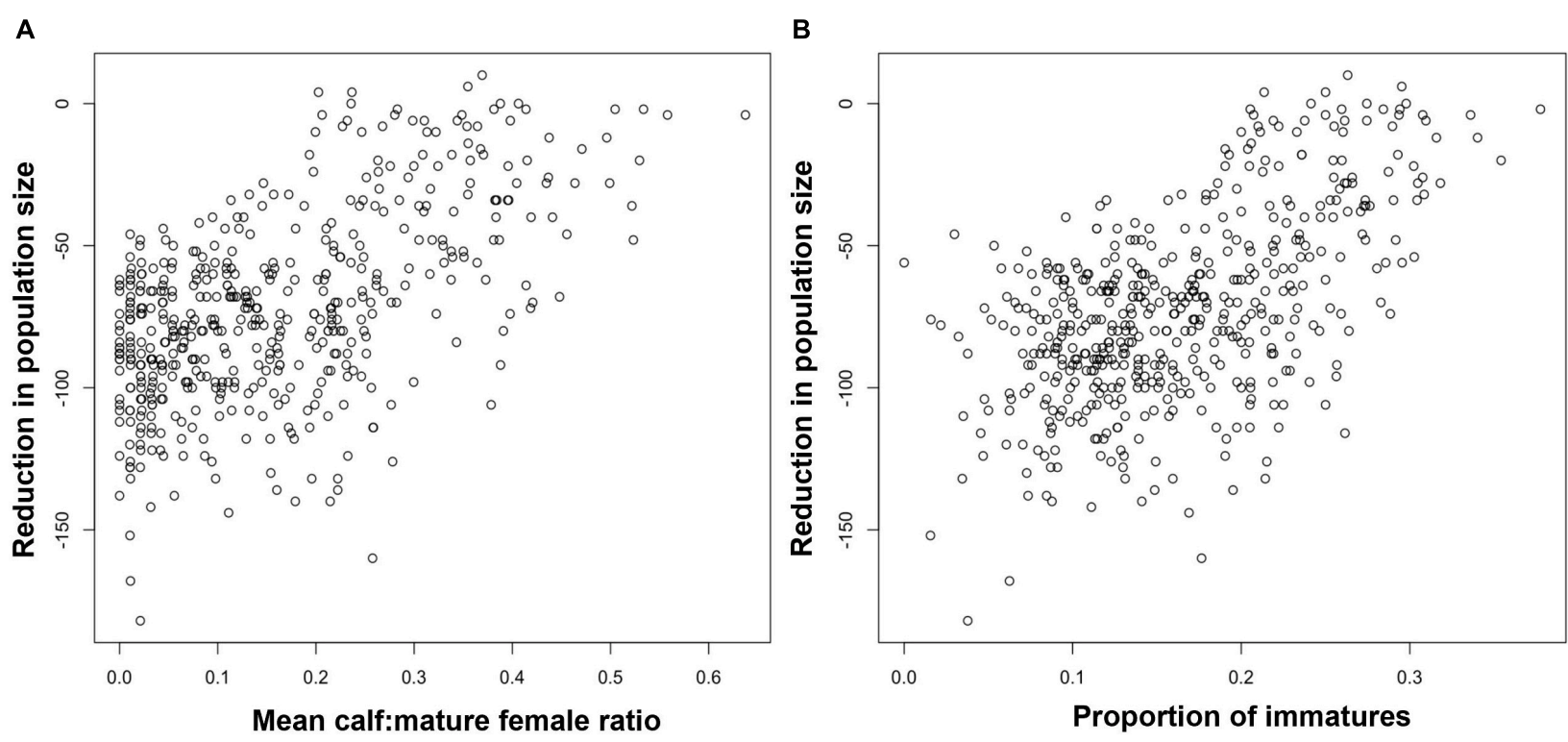

FIGURE 4 | Relationship between the maximum predicted reduction in bottlenose dolphin population size and (A) the average ratio of calves to mature females in the first 3 years of disturbance, (B) the proportion of immature animals in year 5 when environmental variation and demographic stochasticity was included in the simulations.

samples from simulated populations with a growth rate lower than 0.98 (i.e., declining by $2 \%$ per annum) was always less than 0.2 (Figure 5D).

\section{DISCUSSION}

Using a combination of literature review, an expert workshop and additional analysis we identified a set of methodologies for monitoring demographic characteristics and health variables that can be used to inform PCoD analyses for marine mammals.

In general, information on demographic characteristics, such as the ratio of calves to mature females and the proportion of immature animals in the population, can be collected using established approaches. Monitoring of these characteristics is most commonly achieved via capture-recapture techniques (usually photo-ID, although genetic and electronic tagging methods have also been used) that can also provide information on stage-specific survival rates and fertility. Although these approaches are labor intensive, they are well established and capable of providing robust estimates of key demographic variables (Supplementary Table S3). Analysis of population simulation data indicated that some of these demographic characteristics, particularly the proportion of immature animals in the population, can provide an early warning of population decline. This conclusion is supported by analyses of the potential effects of body condition on vital rates using bioenergetics models. For example, Hin et al. (2019) used a dynamic energy budget (DEB) model of the North Atlantic long-finned pilot whale to investigate the potential effects of disturbance on lifetime reproductive success. They found that disturbance could lead to a large reduction in the proportion of calves that survived to weaning. Moretti (2019) used a variant of this model to show a similar effect of disturbance on Blainville's beaked whale.

A wide range of methods can potentially provide information on individual health. However, further validation and standardization of these methods, together with a better understanding of natural variation in the health variables about which they provide information, is needed to advance their utility.

Photo-ID and photogrammetry can be used to provide a visual assessment of health variables such as body condition. Information on features such as the presence of rake marks and epidermal lesions, which may be useful for health assessment and individual identification, can also be collected during visual surveys (Supplementary Table S4). New tools are being developed to monitor the physiology of animals and estimate physiological states and body condition remotely using telemetry (e.g., Ponganis and McDonald, 2015; Williams, 2015; Elmegaard et al., 2016; Ponganis, 2017; McDonald et al., 2018; Costa et al., 2019; Fahlman et al., 2019; Madsen and Van Der Hoop, 2019). Transmission of this information via satellite could allow longitudinal monitoring of these variables over a period of months (Miller et al., 2019).

Hands-on assessment of captive animals, animals in accessible locations (such as seal breeding colonies), and stranded, bycaught or harvested individuals can provide estimates for a range of health variables. However, these animals may not be representative of the population because of sampling biases toward individuals that are easier to catch and handle, or are more likely to be bycaught or strand. Remote tissue sampling can be used to provide information on the same set of health variables, but there may also be issues about the representativeness of the sampled individuals. 

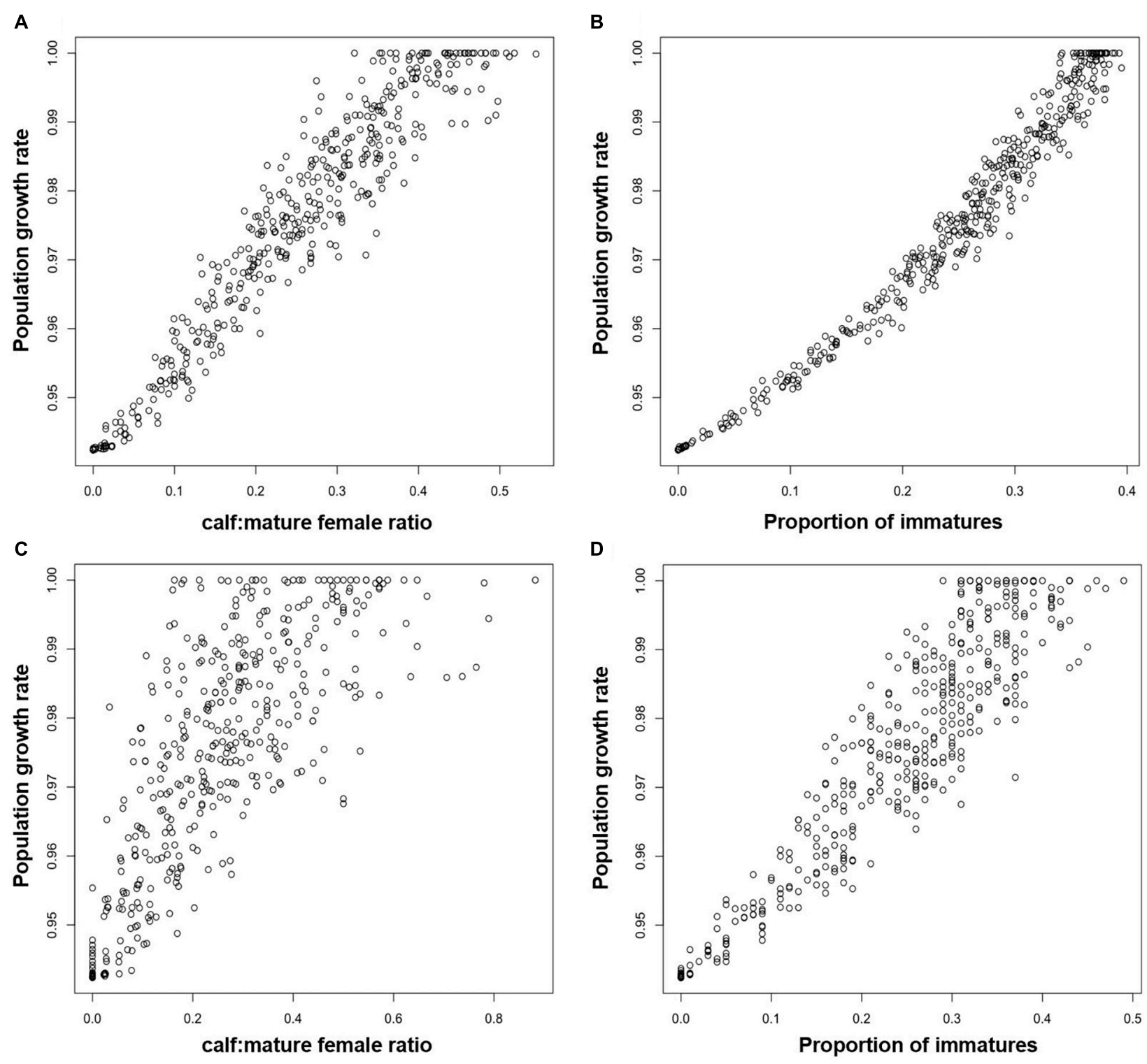

FIGURE $\mathbf{5}$ | Relationship between the long term growth rate of a Blainville's beaked whale population and (A) the ratio of calves to mature females estimated from a random sample of 1,000 animals, (B) the proportion of immature animals estimated from a random sample of 1,000 animals (C) the ratio of calves to mature females estimated from a random sample of 100 animals, (D) the proportion of immature animals estimated from a random sample of 100 animals.

\section{Designing an Appropriate Monitoring Program}

Here we focus on issues that need to be considered in designing a monitoring program that will use the methods identified as appropriate by the literature survey and workshop.

\section{Population Structure}

One of the key pre-requisites for designing a monitoring program is to identify an appropriate unit of assessment. However, this can be challenging for marine mammal populations. In many cases, the unit of assessment will simply be those animals that can be accessed and sampled. Local populations of this kind may not be closed to migration. As a result undocumented, or time-varying immigration and emigration may make it difficult to interpret observed changes in demographic characteristics. It is therefore important that a monitoring program is capable of generating estimates of migration rates. The most appropriate methods for this are capture-recapture analysis, and genetic analysis of tissue samples.

\section{Quantifying Uncertainty}

In order to detect changes over time in demographic characteristics or health measures, it is essential to have reliable estimates of the uncertainty (precision and accuracy) associated with these measurements. Information on levels of 
uncertainty is also a fundamental component of PCoD models. From our review, we determined that information on precision is limited for many of the methods that we considered. The main exception was for the estimates of demographic characteristics that come from capture-recapture analyses. reviewed the use of covariates to improve the precision of capture-recapture analysis, and of information from auxiliary studies to improve estimates of recapture probability (e.g., Hewitt et al., 2010). In photogrammetric analyses, the posture (or orientation) of animals, the turbidity of the water, the altitude and type of the camera, weather conditions and observer measurement error can all contribute to uncertainty in estimates. However, these can quantified (Webster et al., 2010; Christiansen et al., 2018), and biases can be reduced with an appropriate data collection strategy (Koski et al., 2006, 2009, 2013).

\section{Sampling Scale}

The appropriate scale of sampling (both spatial and temporal) will depend on the variables and species of interest, the methods being used and the overall objectives of the monitoring program. In terms of the species of interest, the National Academies of Sciences Engineering and Medicine (2017) identified four species groups, based on their ranging behavior:

- Animals that can be sampled on land or ice;

- Accessible resident populations;

- Species that have large ranges but are accessible at certain times of year or during migrations;

- Open ocean species.

A wide range of monitoring methods can be used with populations that fall into the first three categories. However, as noted in the Results (and see Supplementary Tables S4, S5), sampling open ocean species will always be logistically challenging.

\section{Understanding Natural Variation}

In order to understand observed changes in demographic characteristics or health variables that may be a consequence of disturbance, it is important to document natural variability under undisturbed conditions. Although body condition is a potentially useful measure of health, observed changes in body condition may be the result of a change in environmental quality, perhaps because the population is approaching carrying capacity and competition for resources is high (e.g., Estes et al., 2009), rather than as a result of exposure to disturbance. Body condition also varies markedly seasonally and during different life history stages. For example, the DEB model developed by Hin et al. (2019) indicates that body condition (as estimated by the proportion of body mass available as an energy reserve) of undisturbed lactating pilot whales and their calves may fall to potentially lifethreatening levels during the first year of lactation. It is therefore important, whenever possible, to identify the life history stage of each individual when estimating its body condition.

One way to calibrate changes observed during monitoring is to study a suitable reference population against which the focal population can be compared. For example, Claridge (2013) monitored demographic characteristics of Blainville's beaked whales on AUTEC in the Bahamas and at a study site at Abaco, approximately $150 \mathrm{~km}$ away, where sonar activity is rare. However, Benoit-Bird (2017) observed significant differences in prey distribution and abundance between the two sites. These make it difficult to unequivocally attribute observed differences in demographic characteristics between the two sites to the effects of disturbance (Moretti, 2019).

An alternative approach is to collect information on contextual variables, such as environmental quality and prey resources, at the focal study site and include these as covariates in subsequent analyses. This may involve site-specific prey resource mapping (e.g., Friedlaender et al., 2016), or the inclusion of information on larger scale environmental perturbations, such as the North Atlantic Oscillation (Drinkwater et al., 2003; Greene and Pershing, 2003) or El Niño Southern Oscillation (Tershy et al., 1991; Wilson et al., 2001), that are known to affect primary productivity.

\section{Adding Value to Programs That Monitor Density or Abundance}

The estimation of density or abundance is a standard component of most marine mammal monitoring programs, usually via visual, PAM or capture-recapture surveys (e.g., Wilson et al., 1999). As noted above, the statistical power of such time series data to detect change is often low, because of the uncertainty associated with the individual estimates. For example, Moretti (2019) calculated that, depending on the number of days of sampling each year, 25-30 years of photo-ID data would be required to detect an annual decline of $5 \%$ in the Blainville's beaked whale population at AUTEC. However, standard density and abundance surveys can be augmented with other methods that can provide data on additional demographic and health variables. For example, individual pigmentation patterns can be documented during visual and capture-recapture studies, and for some oceanic dolphin species this information can be used to distinguish between adults and juveniles (Perrin, 1970; Perrin et al., 1976; Herzing, 1997; Bertulli et al., 2016). Photogrammetric data, and biopsy, fecal and blow samples can also be collected during capture-recapture studies and used to provide information on health variables. Information on features such as the presence of rake marks and epidermal lesions, which may be useful for health assessment and individual identification, can be collected during visual and capture-recapture studies (Supplementary Table S4). Capture-recapture studies also provide an opportunity to collect photogrammetric data, and biopsy, fecal and blow samples.

\section{Informing PCoD Analysis}

The key feature of the PCoD framework is that it links behavioral and physiological changes that occur as a response to disturbance to demography via a series of transfer functions. However, as noted above, obtaining the data that is required to parameterize these functions is challenging.

There is considerable scope for using monitoring data to inform the link between disturbance exposure and behavioral and physiological change. For example, Moretti et al. (2014) used PAM data, which was available almost continuously from a fixed hydrophone array, to parameterize a risk function 
relating changes in Blainville's beaked whale deep-diving behavior to received levels of sonar. Short-term telemetry studies have provided similar information (Harris et al., 2018), and it is expected that the incorporation of acoustic dosimeters into satellite tags will make it possible to quantify behavioral and physiological responses to acoustic disturbance over much longer time periods. Such telemetry devices could also provide information on the effects of behavioral and physiology changes on some health variables, particularly body condition (e.g., Costa et al., 2019).

There is less scope for monitoring programs to inform the link between vital rates and health variables, because of the time scales involved and the (often unobserved) contextual variables which complicate assessments. Nevertheless, programs that monitor both health variables and demographic characteristics can be used to infer the nature of this relationship. For example, Rolland et al. (2016) used data from a long-term photo-ID study of north Atlantic right whales to examine the relationship between a composite measure of individual health and demographic trends in the population.

\section{DATA AVAILABILITY STATEMENT}

The datasets generated for this study are available on request to the corresponding author.

\section{REFERENCES}

Aarts, G., Mackenzie, M., McConnell, B., Fedak, M., and Matthiopoulos, J. (2008). Estimating space-use and habitat preference from wildlife telemetry data. Ecography 31, 140-160. doi: 10.1111/j.2007.0906-7590.05236.x

Adamczak, S. K., Pabst, A., Mclellan, W. A., and Thorne, L. H. (2019). Using 3D models to improve estimates of marine mammal size and external morphology. Front. Mar. Sci. 6:334. doi: 10.3389/fmars.2019.00334

Aguilar, N., Reyes, C., Schiav, A., and Hammond, P. S. (2013). Population Parameters of Blainville's and Cuvier's Beaked Whales. Annual Report. Fort Belvoir, VA: Defense Technical Information Center, Office of Naval Research.

Amidan, B. G., Venzin, A. M., and Bramer, L. M. (2015). Multiple Lines of Evidence. Richland, WA: Pacific Northwest National Lab.(PNNL).

Aoki, K., Watanabe, Y. Y., Crocker, D. E., Robinson, P. W., Biuw, M., Costa, D. P., et al. (2011). Northern elephant seals adjust gliding and stroking patterns with changes in buoyancy: validation of at-sea metrics of body density. J. Exp. Biol. 214, 2973-2987. doi: 10.1242/jeb.055137

Apprill, A., Miller, C. A., Moore, M. J., Durban, J. W., Fearnbach, H., and BarrettLennard, L. G. (2017). Extensive core microbiome in drone-captured whale blow supports a framework for health monitoring. Msystems 2, e119-e117.

Ayres, K. L., Booth, R. K., Hempelmann, J. A., Koski, K. L., Emmons, C. K., Baird, R. W., et al. (2012). Distinguishing the impacts of inadequate prey and vessel traffic on an endangered killer whale (Orcinus orca) population. PLoS ONE 7:e36842. doi: 10.1371/journal.pone.0036842

Barlow, J., and Taylor, B. L. (2005). Estimates of sperm whale abundance in the northeastern temperate Pacific from a combined acoustic and visual survey. Mar. Mamm. Sci. 21, 429-445. doi: 10.1111/j.1748-7692.2005. tb01242.x

Barlow, J., Tyack, P. L., Johnson, M. P., Baird, R. W., Schorr, G. S., Andrews, R. D., et al. (2013). Trackline and point detection probabilities for acoustic surveys of Cuvier's and Blainville's beaked whales. J. Acoust. Soc. Am. 134, 2486-2496. doi: $10.1121 / 1.4816573$

Baruch, D. E., Kanter, J. W., Busch, A. M., Plummer, M. D., Tsai, M., Rusch, L. C., et al. (2009). "Lines of evidence in support of FAP," in A Guide to Functional Analytic Psychotherapy, ed. M. Tsai, R. J. Kohlenberg, J. W. Kanter,

\section{AUTHOR CONTRIBUTIONS}

$\mathrm{CB}$ and $\mathrm{JH}$ designed and performed the research. All authors analyzed the data, workshop outputs and wrote the manuscript.

\section{FUNDING}

This work was sponsored by the Office of Naval Research: Marine Mammal Biology Program, under award N000141612858.

\section{ACKNOWLEDGMENTS}

We are grateful to the workshop participants (see Supplementary Table S1), Prof. Len Thomas, Prof. Daniel Costa, Dr. Catriona Harris, Dr. Leslie New, Dr. Robert Schick and Dr. Enrico Pirotta for their input.

\section{SUPPLEMENTARY MATERIAL}

The Supplementary Material for this article can be found online at: https://www.frontiersin.org/articles/10.3389/fmars. 2020.00115/full\#supplementary-material

B. Kohlenberg, W. C. Follette, and G. M. Callaghan (Berlin: Springer), 1-16. doi: 10.1007/978-0-387-09787-9_2

Bassos-Hull, K., Perrtree, R. M., Shepard, C. C., Schilling, S., Barleycorn, A. A., Allen, J. B., et al. (2013). Long-term site fidelity and seasonal abundance estimates of common bottlenose dolphins (Tursiops truncatus) along the southwest coast of Florida and responses to natural perturbations. J. Cetacean Res. Manage. 13, 19-30.

Baumgartner, M. F., and Fratantoni, D. M. (2008). Diel periodicity in both sei whale vocalization rates and the vertical migration of their copepod prey observed from ocean gliders. Limnol. Oceanogr. 53, 2197-2209. doi: 10.4319/lo.2008.53. 5_part_2.2197

Baumgartner, M. F., Fratantoni, D. M., Hurst, T. P., Brown, M. W., Cole, T. V., Van Parijs, S. M., et al. (2013). Real-time reporting of baleen whale passive acoustic detections from ocean gliders. J. Acoust. Soc. Am. 134, 1814-1823. doi: $10.1121 / 1.4816406$

Beltran, R. S., Ruscher-Hill, B., Kirkham, A. L., and Burns, J. M. (2018). An evaluation of three-dimensional photogrammetric and morphometric techniques for estimating volume and mass in Weddell seals Leptonychotes weddellii. PLoS ONE 13:e0189865. doi: 10.1371/journal.pone. 0189865

Bennett, A., Preston, V., Woo, J., Chandra, S., Diggins, D., Chapman, R., et al. (2015). "Autonomous vehicles for remote sample collection in difficult conditions: enabling remote sample collection by marine biologists," in Technologies for Practical Robot Applications (TePRA), 2015 IEEE International Conference (New York, NY: IEEE).

Benoit-Bird, K. J. (2017). "Linking deep-water prey fields with odontocete population structure and behavior," in Marine Mammal \& Biology Program Review, Book of Abstracts 20-24 March 2017, (Arlington, VA: Office of Naval Research).

Bertulli, C. G., Galatius, A., Kinze, C. C., Rasmussen, M. H., Keener, W., and Webber, M. A. (2016). Color patterns in white-beaked dolphins (Lagenorhynchus albirostris) from Iceland. Mar. Mammal Sci. 32, 1072-1098. doi: $10.1111 / \mathrm{mms} .12312$

Bilgmann, K., Moller, L. M., Harcourt, R. G., Kemper, C. M., and Beheregaray, L. B. (2011). The use of carcasses for the analysis of cetacean population genetic 
structure: a comparative study in two dolphin species. PLoS ONE 6:e20103. doi: 10.1371/journal.pone.0020103

Biuw, M., Boehme, L., Guinet, C., Hindell, M., Costa, D., Charrassin, J.-B., et al. (2007). Variations in behavior and condition of a Southern Ocean top predator in relation to in situ oceanographic conditions. Proc. Natl. Acad. Sci. U.S.A. 104, 13705-13710. doi: 10.1073/pnas.0701121104

Biuw, M., McConnell, B., Bradshaw, C. J., Burton, H., and Fedak, M. (2003). Blubber and buoyancy: monitoring the body condition of free-ranging seals using simple dive characteristics. J. Exp. Biol. 206, 3405-3423. doi: 10.1242/jeb. 00583

Blundell, G. M., and Pendleton, G. W. (2008). Estimating age of harbor seals (Phoca vitulina) with incisor teeth and morphometrics. Mar. Mammal Sci. 24, 577-590. doi: 10.1111/j.1748-7692.2008.00194.x

Booth, C., Donovan, C., Plunkett, R., and Harwood, J. (2016). Using an Interim PCoD Protocol to Assess the Effects of Disturbance Associated with US Navy Exercises on Marine Mammal Populations. Arlington, VA: US Office of Naval Research.

Bradford, A. L., Weller, D. W., Punt, A. E., Ivashchenko, Y. V., Burdin, A. M., Vanblaricom, G. R., et al. (2012). Leaner leviathans: body condition variation in a critically endangered whale population. J. Mammal. 93, 251-266. doi: 10.1644/11-mamm-a-091.1

Büche, B., and Stubbings, E. (2016). Grey Seal Breeding Census Skomer Island 2015. Cardigan: Wildlife Trust of South and West Wales.

Buckland, S. T., Anderson, D. R., Burnham, K. P., Laake, J. L., Borchers, D. L., and Thomas, L. (2001). Introduction to Distance Sampling. Estimating abundance of biological populations. Oxford: Oxford University Press.

Buckland, S. T., Anderson, D. R., Burnham, K. P., Laake, J. L., Borchers, D. L., and Thomas, L. (2004). Advanced Distance Sampling. Estimating abundance of biological populations. Oxford: Oxford University Press.

Burnett, J. D., Lemos, L., Barlow, D., Wing, M. G., Chandler, T., and Torres, L. G. (2019). Estimating morphometric attributes of baleen whales with photogrammetry from small UASs: a case study with blue and gray whales. Mar. Mammal Sci. 35, 108-139. doi: 10.1111/mms.12527

Carlén, I., Thomas, L., Carlström, J., Amundin, M., Teilmann, J., Tregenza, N., et al. (2018). Basin-scale distribution of harbour porpoises in the Baltic Sea provides basis for effective conservation actions. Biol. Conserv. 226, 42-53. doi: 10.1016/j.biocon.2018.06.031

Carroll, E., Patenaude, N., Childerhouse, S., Kraus, S., Fewster, R., and Baker, C. (2011). Abundance of the New Zealand subantarctic southern right whale population estimated from photo-identification and genotype mark-recapture. Mar. Biol. 158, 2565-2575. doi: 10.1007/s00227-0111757-9

Champagne, C. D., Kellar, N. M., Crocker, D. E., Wasser, S. K., Booth, R. K., Trego, M. L., et al. (2017). Blubber cortisol qualitatively reflects circulating cortisol concentrations in bottlenose dolphins. Mar. Mammal Sci. 33, 134-153. doi: $10.1111 / \mathrm{mms} .12352$

Champagne, C. D., Kellar, N. M., Trego, M. L., Brendan, D., Rudy, B., Wasser, S. K., et al. (2018). Comprehensive endocrine response to acute stress in the bottlenose dolphin from serum, blubber, and feces. Gen. Compar. Endocrinol. 266, 178-193. doi: 10.1016/j.ygcen.2018.05.015

Cheney, B., Graham, I. M., Barton, T., Hammond, P. S., and Thompson, P. M. (2018a). Site Condition Monitoring of Bottlenose Dolphins Within the Moray Firth Special Area of Conservation: 2014-2016. Inverness: Scottish National Heritage.

Cheney, B., Wells, R., Barton, T., and Thompson, P. (2018b). Laser photogrammetry reveals variation in growth and early survival in freeranging bottlenose dolphins. Anim. Conserv. 21, 252-261. doi: 10.1111/acv. 12384

Christiansen, F., Dujon, A. M., Sprogis, K. R., Arnould, J. P. Y., and Bejder, L. (2016). Noninvasive unmanned aerial vehicle provides estimates of the energetic cost of reproduction in humpback whales. Ecosphere 7:e01468. doi: $10.1002 /$ ecs 2.1468

Christiansen, F., Sironi, M., Moore, M. J., Di Martino, M., Ricciardi, M., Warick, H. A., et al. (2019). Estimating body mass of free-living whales using aerial photogrammetry and 3D volumetrics. Methods Ecol. Evol. 2019, 1-11.

Christiansen, F., Vivier, F., Charlton, C., Ward, R., Amerson, A., Burnell, S., et al. (2018). Maternal body size and condition determine calf growth rates in Southern right whales. Mar. Ecol. Prog. Ser. 592, 267-282.
Claridge, D. E. (2013). Population Ecology of Blainville's Beaked Whales (Mesoplodon densirostris). PhD Thesis, University of St Andrews, St. Andrews.

Cordes, L. S., and Thompson, P. M. (2015). Mark-resight estimates of seasonal variation in harbor seal abundance and site fidelity. Populat. Ecol. 57, 467-472. doi: 10.1007/s10144-015-0496-z

Costa, D. P., Crocker, D. E., and Huckstadt, L. A. (2019). “Developing metrics of animal condition aand their linkage to vital rates: Further development of the PCoD model," in Marine Mammal \& Biology Program Review, Book of Abstracts 23-26 April 2019 (Arlington, VA: Office of Naval Research).

Costa, D. P., Croxall, J. P., and Duck, C. D. (1989). Foraging energetics of antartic fur seals in relation to changes in prey availability. Ecology 70, 596-606. doi: $10.2307 / 1940211$

Costa, D. P., Schwarz, L., Robinson, P., Schick, R. S., Morris, P. A., Condit, R., et al. (2016). "A bioenergetics approach to understanding the population consequences of disturbance: elephant seals as a model system," in The Effects of Noise on Aquatic Life II, eds A. N. Popper and A. Hawkins (Berlin: Springer), 161-169. doi: 10.1007/978-1-4939-2981-8_19

Crocker, D. E., Boeuf, B. J. L., and Costa, D. P. (1997). Drift diving in female northern elephant seals: implications for food processing. Can. J. Zool. 75, 27-39. doi: 10.1139/z97-004

Currey, R. J., Dawson, S. M., Slooten, E., Schneider, K., Lusseau, D., Boisseau, O. J., et al. (2009). Survival rates for a declining population of bottlenose dolphins in Doubtful Sound, New Zealand: an information theoretic approach to assessing the role of human impacts. Aquat. Conserv. Mar. Freshw. Ecosyst. 19, 658-670. doi: 10.1002/aqc.1015

Dawson, S. M., Bowman, M. H., Leunissen, E., and Sirguey, P. (2017). Inexpensive aerial photogrammetry for studies of whales and large marine animals. Front. Mar. Sci. 4:366. doi: 10.3389/fmars.2017.00366

Dawson, S., Chessum, C., Hunt, P., and Slooten, E. (1995). An inexpensive, stereophotographic technique to measure sperm whales from small boats. Report of the International Whaling Commission 45, 431-436.

De Wet, M. (2013). A Systematic Health Assessment of Two Dolphin Species by-Caught in Shark Nets off the KwaZulu-Natal coast, South Africa. MSc Dissertation, University of Pretoria, Pretoria.

Deagle, B. E., and Tollit, D. J. (2007). Quantitative analysis of prey DNA in pinniped faeces: potential to estimate diet composition? Conserv. Genet. 8, 743-747. doi: 10.1007/s10592-006-9197-7

DeRuiter, S. L., Boyd, I. L., Claridge, D. E., Clark, C. W., Gagnon, C., Southall, B. L., et al. (2013). Delphinid whistle production and call matching during playback of simulated military sonar. Mar. Mammal Sci. 29, E46-E59.

Donovan, C., Harwood, J., King, S., Booth, C., Caneco, B., and Walker, C. (2016). "Expert elicitation methods in quantifying the consequences of acoustic disturbance from offshore renewable energy developments," in The Effects of Noise on Aquatic Life II, eds A. N. Popper and A. Hawkins (Berlin: Springer), 231-237. doi: 10.1007/978-1-4939-2981-8_27

Drinkwater, K. F., Belgrano, A., Borja, A., Conversi, A., Edwards, M., Greene, C. H., et al. (2003). The Response of Marine Ecosystems to Climate Variability Associated with the North Atlantic Oscillation. Hoboken, NJ: Wiley Online Library.

Dunstan, J., Gledhell, A., Hall, A., Miller, P., and Ramp, C. (2012). "Quantification of the hormones progesterone and cortisol in whale breath samples using novel, non-invasive sampling and analysis with highly-sensitive ACQUITY UPLC and Xevo TQ-S," in Waters Application Note (Milford, MA: Waters Corporation).

Durban, J., Fearnbach, H., Barrett-Lennard, L., Perryman, W., and Leroi, D. (2015). Photogrammetry of killer whales using a small hexacopter launched at sea. J. Unmanned Vehicle Syst. 3, 131-135. doi: 10.1139/juvs-20150020

Durban, J., and Parsons, K. (2006). Laser-metrics of free-ranging killer whales. Mar. Mammal Sci. 22, 735-743. doi: 10.1111/j.1748-7692.2006. 00068.x

Durban, J. W., Moore, M. J., Chiang, G., Hickmott, L. S., Bocconcelli, A., Howes, G., et al. (2016). Photogrammetry of blue whales with an unmanned hexacopter. Mar. Mammal Sci. 32, 1510-1515. doi: 10.1111/mms. 12328

Elmegaard, S. L., Johnson, M., Madsen, P. T., and Mcdonald, B. I. (2016). Cognitive control of heart rate in diving harbor porpoises. Curr. Biol. 26, R1175-R1176. doi: 10.1016/j.cub.2016.10.020 
Estes, J., Doak, D., Springer, A., and Williams, T. (2009). Causes and consequences of marine mammal population declines in southwest Alaska: a food-web perspective. Philos. Trans. R. Soc. Lond. B Biol. Sci. 364, 1647-1658. doi: 10. 1098/rstb.2008.0231

Fahlman, A., Miedler, S., Garcia-Parraga, D., Marti-Bonmati, L., and Brodsky, M. (2019). "Cardiorespiratory physiology in the bottlenose dolphin before and after breath-holding and exercise," in Marine Mammal \& Biology Program Review, Book of Abstracts 23-26 April 2019 (Arlington, VA: Office of Naval Research).

Fair, P. A., Schaefer, A. M., Romano, T. A., Bossart, G. D., Lamb, S. V., and Reif, J. S. (2014). Stress response of wild bottlenose dolphins (Tursiops truncatus) during capture-release health assessment studies. Gen. Compar. Endocrinol. 206, 203-212. doi: 10.1016/j.ygcen.2014.07.002

Falcone, E. A., Schorr, G. S., Douglas, A. B., Calambokidis, J., Henderson, E., Mckenna, M. F., et al. (2009). Sighting characteristics and photo-identification of Cuvier's beaked whales (Ziphius cavirostris) near San Clemente Island, California: a key area for beaked whales and the military? Mar. Biol. 156, 2631-2640. doi: 10.1007/s00227-009-1289-8

Fearnbach, H., Durban, J. W., Ellifrit, D. K., and Balcomb, K. C. (2015). Individual-based photogrammetric measures of length, growth and shape to infer body condition and reproductive status of Southern Resident Killer Whales. Unpublished report by Center for Whale Research and NOAA, USA.

Fettermann, T., Fiori, L., Bader, M., Doshi, A., Breen, D., Stockin, K. A., et al. (2019). Behaviour reactions of bottlenose dolphins (Tursiops truncatus) to multirotor Unmanned Aerial Vehicles (UAVs). Sci. Rep. 9:8558. doi: 10.1038/ s41598-019-44976-9

Fiori, L., Doshi, A., Martinez, E., Orams, M. B., and Bollard-Breen, B. (2017). The use of unmanned aerial systems in marine mammal research. Remote Sens. 9:543. doi: $10.3390 / \mathrm{rs} 9060543$

Ford, M. J., Hanson, M. B., Hempelmann, J. A., Ayres, K. L., Emmons, C. K., Schorr, G. S., et al. (2011). Inferred paternity and male reproductive success in a killer whale (Orcinus orca) population. J. Heredity 102, 537-553. doi: 10.1093/jhered/ esr067

Fossi, M., Marsili, L., Junin, M., Castello, H., Lorenzani, J., Casini, S., et al. (1997). Use of nondestructive biomarkers and residue analysis to assess the health status of endangered species of pinnipeds in the southwest Atlantic. Mar. Pollut. Bull. 34, 157-162. doi: 10.1016/s0025-326x(96) 00073-2

Friedlaender, A., Hazen, E., Goldbogen, J., Stimpert, A., Calambokidis, J., and Southall, B. (2016). Prey-mediated behavioral responses of feeding blue whales in controlled sound exposure experiments. Ecol. Appl. 26, 1075-1085. doi: $10.1002 / 15-0783$

Gabriele, C. M., Neilson, J. L., Straley, J. M., Baker, C. S., Cedarleaf, J. A., and Saracco, J. F. (2017). Natural history, population dynamics, and habitat use of humpback whales over 30 years on an Alaska feeding ground. Ecosphere 8:e01641. doi: $10.1002 / \mathrm{ecs} 2.1641$

Galatius, A., Jansen, O. E., and Kinze, C. C. (2013). Parameters of growth and reproduction of white-beaked dolphins (Lagenorhynchus albirostris) from the North Sea. Mar. Mammal Sci. 29, 348-355. doi: 10.1111/j.1748-7692.2012. 00568.x

Geoghegan, J., Pirotta, V., Harvey, E., Smith, A., Buchmann, J., Ostrowski, M., et al. (2018). Virological sampling of inaccessible wildlife with drones. Viruses 10:300. doi: $10.3390 / v 10060300$

Gerrodette, T., Taylor, B. L., Swift, R., Rankin, S., Jaramillo-Legorreta, A. M., and Rojas-Bracho, L. (2011). A combined visual and acoustic estimate of 2008 abundance, and change in abundance since 1997, for the vaquita, Phocoena sinus. Mar. Mammal Sci. 27, E79-E100.

Gillespie, D., Berggren, P., Brown, S., Kuklik, I., Lacey, C., Lewis, T., et al. (2005). Relative abundance of harbour porpoises (Phocoena phocoena) from acoustic and visual surveys of the Baltic Sea and adjacent waters during 2001 and 2002. J. Cetacean. Res. Manage. 7, 51-57.

Gillespie, D., Leaper, R., Gordon, J., and Macleod, K. (2010). An integrated data collection system for line transect surveys. J. Cetacean Res. Manage. 11, 217-227.

Greene, C. H., and Pershing, A. J. (2003). The flip-side of the North Atlantic Oscillation and modal shifts in slope-water circulation patterns. Limnol. Oceanogr. 48, 319-322. doi: 10.4319/lo.2003.48. 1.0319
Greig, D. J., Gulland, F. M. D., Rios, C. A., and Hall, A. J. (2010). Hematology and serum chemistry in stranded and wild-caught harbor seals in central California: reference intervals, predictors of survival, and parameters affecting blood variables. J. Wildlife Dis. 46, 1172-1184. doi: 10.7589/0090-3558-46. 4.1172

Gryzbek, M.K. (2013). A Visual Body Condition Index for Bottlenose Dolphins (Tursiops truncatus). MSc Thesis, University of Florida, Gainesville.

Hall, A. J., Gulland, F. M., Hammond, J. A., Schwacke, L. H., Boyd, I., Bowen, W., et al. (2010). "Epidemiology, disease, and health assessment," in Marine Mammal Ecology and Conservation, eds I. L. Boyd, W. Don Bowen, S. J. Iverson (New York, NY: Oxford University Press), 144-164.

Hansen, L. J., and Wells, R. S. (1996). Bottlenose Dolphin Health Assessment: Field Report on Sampling Near Beaufort, North Carolina, during July, 1995. Biscayne, FL: US Department of Commerce, National Oceanic and Atmospheric Administration, National Marine Fisheries Service, Southeast Fisheries Science Center, Charleston Laboratory.

Hanson, M. B., Baird, R. W., Ford, J. K., Hempelmann-Halos, J., Van Doornik, D. M., Candy, J. R., et al. (2010). Species and stock identification of prey consumed by endangered southern resident killer whales in their summer range. Endang. Spec. Res. 11, 69-82. doi: 10.3354/esr00263

Harris, C. M., Thomas, L., Falcone, E. A., Hildebrand, J., Houser, D., Kvadsheim, P. H., et al. (2018). Marine mammals and sonar: dose-response studies, the risk-disturbance hypothesis and the role of exposure context. J. Appl. Ecol. 55, 396-404. doi: 10.1111/1365-2664.12955

Harris, D., Matias, L., Thomas, L., Harwood, J., and Geissler, W. H. (2013). Applying distance sampling to fin whale calls recorded by single seismic instruments in the northeast Atlantic. J. Acoust. Soc. Am. 134, 3522-3535. doi: $10.1121 / 1.4821207$

Harris, D.V. (2012). Estimating Whale Abundance Using Sparse Hydrophone Arrays. PhD Thesis, University of St. Andrews, St. Andrews.

Harvey, J. (1989). Assessment of errors associated with harbour seal (Phoca vitulina) faecal sampling. J. Zool. 219, 101-111. doi: 10.1111/j.1469-7998.1989. tb02569.x

Harwood, J., and Booth, C. (2016). The Application of An Interim PCoD (PCoD Lite) Protocol and Its Extension to Other Marine Mammal Populations and Sites. Arlington, VA: US Office of Naval Research. doi: 10.1111/j.1469-7998. 1989.tb02569.x

Harwood, J., King, S., Schick, R., Donovan, C., and Booth, C. (2014). A protocol for implementing the interim population consequences of disturbance $(\mathrm{PCoD})$ approach: quantifying and assessing the effects of UK offshore renewable energy developments on marine mammal populations. Scott. Mar. Freshw. Sci. 5. Available at: http://www.gov.scot/Resource/0044/00443360.pdf

Herman, D. P., Matkin, C. O., Ylitalo, G. M., Durban, J. W., Hanson, M. B., Dahlheim, M. E., et al. (2008). Assessing age distributions of killer whale Orcinus orca populations from the composition of endogenous fatty acids in their outer blubber layers. Mar. Ecol. Prog. Ser. 372, 289-302. doi: 10.3354/meps 07709

Herzing, D. L. (1997). The life history of free-ranging Atlantic spotted dolphins (Stenella frontalis): age classes, color phases, and female reproduction. Mar. Mammal Sci. 13, 576-595. doi: 10.1111/j.1748-7692.1997.tb0 0085.x

Hewitt, D. A., Janney, E. C., Hayes, B. S., and Shively, R. S. (2010). Improving inferences from fisheries capture-recapture studies through remote detection of PIT tags. Fisheries 35, 217-231. doi: 10.1577/1548-8446-35. 5.217

Hin, V., Harwood, J., and de Roos, A. M. (2019). Bio-energetic modeling of mediumsized cetaceans shows high sensitivity to disturbance in seasons of low resource supply. Ecol. Appl. 29:e01903. doi: 10.1002/eap.1903

Hindell, M. A., Mcmahon, C. R., Bester, M. N., Boehme, L., Costa, D., Fedak, M. A., et al. (2016). Circumpolar habitat use in the southern elephant seal: implications for foraging success and population trajectories. Ecosphere 7:e01213. doi: 10. $1002 /$ ecs 2.1213

Hogg, C., Rogers, T., Shorter, A., Barton, K., Miller, P., and Nowacek, D. (2009). Determination of steroid hormones in whale blow: it is possible. Mar. Mammal Sci. 25, 605-618. doi: 10.1111/j.1748-7692.2008.00277.x

Hohn, A. A., and Fernandez, S. (1999). Biases in dolphin age structure due to age estimation technique. Mar. Mammal Sci. 15, 1124-1132. doi: 10.1111/j.17487692.1999.tb00881.x 
Hughes-Hanks, J., Rickard, L., Panuska, C., Saucier, J., O'hara, T., Dehn, L., et al. (2005). Prevalence of Cryptosporidium spp. and Giardia spp. in five marine mammal species. J. Parasitol. 91, 1225-1228. doi: 10.1645/ge-545r.1

Hunt, K. E., Lysiak, N. S., Matthews, C. J. D., Lowe, C., Ajo, A. F., Dillon, D., et al. (2018). Multi-year patterns in testosterone, cortisol and corticosterone in baleen from adult males of three whale species. Conserv. Physiol. 6:coy049.

Hunt, K. E., Moore, M. J., Rolland, R. M., Kellar, N. M., Hall, A. J., Kershaw, J., et al. (2013). Overcoming the challenges of studying conservation physiology in large whales: a review of available methods. Conserv. Physiol. 1:cot006. doi: 10.1093/conphys/cot006

Hunt, K. E., Robbins, J., Buck, C. L., Berube, M., and Rolland, R. M. (2019). Evaluation of fecal hormones for noninvasive research on reproduction and stress in humpback whales (Megaptera novaeangliae). Gen. Compar. Endocrinol. 280, 24-34. doi: 10.1016/j.ygcen.2019.04.004

Hunt, K. E., Trites, A. W., and Wasser, S. K. (2004). Validation of a fecal glucocorticoid assay for Steller sea lions (Eumetopias jubatus). Physiol. Behav. 80, 595-601. doi: 10.1016/j.physbeh.2003.10.017

Ireland, D.S. (2004). Mass Estimation of Weddell Seals Through Photogrammetry. MSc Thesis, Montana State University-Bozeman College of Letters \& Science, Bozeman, MT.

Jewell, R., Thomas, L., Harris, C. M., Kaschner, K., Wiff, R., Hammond, P. S., et al. (2012). Global analysis of cetacean line-transect surveys: detecting trends in cetacean density. Mar. Ecol. Prog. Ser. 453, 227-240. doi: 10.3354/meps 09636

Joblon, M. J., Pokras, M. A., Morse, B., Harry, C. T., Rose, K. S., Sharp, S. M., et al. (2014). Body condition scoring system for delphinids based on short-beaked common dolphins (Delphinus delphis). J. Mar. Anim. Ecol. 7, 5-13.

Johnson, M. P., and Tyack, P. L. (2003). A digital acoustic recording tag for measuring the response of wild marine mammals to sound. IEEE J. Ocean. Eng. 28, 3-12. doi: 10.1109/joe.2002.808212

Jones, R. E. (1981). Food habits of smaller marine mammals from northern California. Proc. Calif. Acad. Sci. 42, 409-433.

Karczmarski, L., Würsig, B., Gailey, G., Larson, K. W., and Vanderlip, C. (2005). Spinner dolphins in a remote Hawaiian atoll: social grouping and population structure. Behav. Ecol. 16, 675-685. doi: 10.1093/beheco/ari028

Kellar, N. M., Keliher, J., Trego, M. L., Catelani, K. N., Hanns, C., George, J. C., et al. (2013). Variation of bowhead whale progesterone concentrations across demographic groups and sample matrices. Endangered Spec. Res. 22, 61-72. doi: $10.3354 /$ esr00537

Kellar, N. M., Trego, M. L., Marks, C. I., Chivers, S. J., Danil, K., and Archer, F. I. (2009). Blubber testosterone: a potential marker of male reproductive status in short-beaked common dolphins. Mar. Mammal Sci. 25, 507-522. doi: $10.1016 /$ j.ygcen.2019.06.006

King, S. L., Schick, R. S., Donovan, C., Booth, C. G., Burgman, M., Thomas, L., et al. (2015). An interim framework for assessing the population consequences of disturbance. Methods Ecol. Evol. 6, 1150-1158. doi: 10.1007/978-1-4939-2981849

Kjeld, M., Ólafsson, Ö., Víkingsson, G. A., and Sigurjónsson, J. (2006). Sex hormones and reproductive status of the North Atlantic fin whales (Balaenoptera physalus) during the feeding season. Aquat. Mammals 32:75. doi: 10.1578/am.32.1.2006.75

Klinck, H., Mellinger, D. K., Klinck, K., Bogue, N. M., Luby, J. C., Jump, W. A., et al. (2012). Near-real-time acoustic monitoring of beaked whales and other cetaceans using a Seaglider ${ }^{\text {TM }}$. PLOS ONE 7:e36128. doi: 10.1371/journal.pone. 0036128

Kogi, K., Hishii, T., Imamura, A., Iwatani, T., and Dudzinski, K. M. (2004). Demographic parameters of indo-pacific bottlenose dolphins (Tursiops aduncus) Around Mikura Island. Jpn. Mar. Mammal Sci. 20, 510-526. doi: 10.1111/j.1748-7692.2004.tb01176.x

Koopman, H. N., Iverson, S. J., and Read, A. (2003). High concentrations of isovaleric acid in the fats of odontocetes: variation and patterns of accumulation in blubber vs. stability in the melon. J. Compar. Physiol. B Biochem. Syst. Environ. Physiol. 173, 247-261. doi: 10.1007/s00360-0030329-9

Koski, W., Rugh, D., Punt, A., and Zeh, J. (2006). An approach to minimise bias in estimation of the length-frequency distribution of bowhead whales (Balaena mysticetus) from aerial photogrammetric data. J. Cetacean Res. Manage. 8:45.
Koski, W., Zeh, J., and George, J. (2008). A calf index for monitoring reproductive success in the Bering-Chukchi-Beaufort Seas bowhead whale (Balaena mysticetus) population. J. Cetacean Res. Manage. 10, 99-106.

Koski, W. R., Allen, T., Ireland, D., Buck, G., Smith, P. R., Macrander, A. M., et al. (2009). Evaluation of an unmanned airborne system for monitoring marine mammals. Aquat. Mammals 35:347. doi: 10.1578/am.35.3. 2009.347

Koski, W. R., Thomas, T. A., Funk, D. W., and Macrander, A. M. (2013). Marine mammal sightings by analysts of digital imagery versus aerial surveyors: a preliminary comparison. J. Unmanned Veh. Syst. 1, 25-40. doi: 10.1139/juvs2013-0015

Kuningas, S., Similä, T., and Hammond, P. S. (2014). Population size, survival and reproductive rates of northern Norwegian killer whales (Orcinus orca) in 1986-2003. J. Mar. Biol. Assoc. U.K. 94, 1277-1291. doi: 10.1017/s00253154130 00933

Laidre, K. L., and Heide-Jorgensen, M. P. (2012). Spring partitioning of disko bay, west greenland, by arctic and subarctic baleen whales. ICES J. Mar. Sci. 69, 1226-1233. doi: 10.1093/icesjms/fss095

Lukacs, P. M., and Burnham, K. P. (2005). Review of capture-recapture methods applicable to noninvasive genetic sampling. Mol. Ecol. 14, 3909-3919. doi: 10.1111/j.1365-294x.2005.02717.x

Madsen, P., and Van Der Hoop, J. (2019). "RATE: respiratory acoustics to estimate energy," in Marine Mammal \& Biology Program Review, Book of Abstracts 23-26 April 2019 (Arlington, VA: Office of Naval Research).

Marques, T. A., Thomas, L., Ward, J., Dimarzio, N., and Tyack, P. L. (2009). Estimating cetacean population density using fixed passive acoustic sensors: an example with Blainville's beaked whales. J. Acoust. Soc. Am. 125, 1982-1994. doi: $10.1121 / 1.3089590$

Mason, E. (2017). Quantifying Photogrammetric Accuracy for Measuring Humpback Whales Using Unmanned Aerial Systems. Durham: Duke University).

Mate, B., Mesecar, R., and Lagerquist, B. (2007). The evolution of satellitemonitored radio tags for large whales: one laboratory's experience. Deep-Sea Res Part II 54, 224-247. doi: 10.1016/j.dsr2.2006.11.021

Mate, B. R., Irvine, L. M., and Palacios, D. M. (2016). The development of an intermediate-duration tag to characterize the diving behavior of large whales. Ecol. Evol. 7, 585-595. doi: 10.1002/ece3.2649

Mate, B. R., Krutzikowsky, G. K., and Winson, M. H. (2000). Satellite-monitored movements of radio-tagged bowhead whales in the Beaufort and Chukchi seas during the late-summer feeding season and fall migration. Can. J. Zool. 78, 1168-1181. doi: 10.1139/z00-045

Matthews, J., Steiner, L., and Gordon, J. (2001). Mark-recapture analysis of sperm whale (Physeter macrocephalus) photo-id data from the Azores (1987-1995). J. Cetacean Res. Manage. 3, 219-226.

Mcclintock, B. T., King, R., Thomas, L., Matthiopoulos, J., McConnell, B. J., and Morales, J. M. (2012). A general discrete-time modeling framework for animal movement using multistate random walks. Ecol. Monogr. 82, 335-349. doi: 10.1890/11-0326.1

McClintock, B. T., Russell, D. J. F., Matthiopoulos, J., and King, R. (2013). Combining individual animal movement and ancillary biotelemetry data to investigate population-level activity budgets. Ecology 94, 838-849. doi: 10.1890/ 12-0954.1

McConnell, B., Beaton, R., Bryant, E., Hunter, C., Lovell, P., and Hall, A. (2004). Phoning home-a new GSM mobile phone telemetry system to collect markrecapture data. Mar. Mammal Sci. 20, 274-283. doi: 10.1111/j.1748-7692.2004. tb01156.x

McDonald, B. I., Johnson, M., and Madsen, P. T. (2018). Dive heart rate in harbour porpoises is influenced by exercise and expectations. J. Exp. Biol. 221:jeb168740. doi: $10.1242 / \mathrm{jeb} .168740$

McDonald, M. A., and Fox, C. G. (1999). Passive acoustic methods applied to fin whale population density estimation. J. Acoust. Soc. Am. 105, 2643-2651. doi: $10.1121 / 1.5126692$

McFadden, K. W., Worthy, G. A., and Lacher, T. E. Jr. (2006). Photogrammetric estimates of size and mass in Hawaiian monk seals (Monachus schauinslandi). Aquat. Mammals 32:31. doi: 10.1578/am.32.1.2006.31

Meise, K., Mueller, B., Zein, B., and Trillmich, F. (2014). Applicability of single-camera photogrammetry to determine body dimensions of pinnipeds: 
galapagos sea lions as an example. PLoS ONE 9:e101197. doi: 10.1371/journal. pone. 0101197

Mellinger, D. K., and Barlow, J. (2003). Future Directions for Acoustic Marine Mammal Surveys: Stock Assessment and Habitat Use: Report of a Workshop Held in La Jolla, California, 20-22 November 2002. Biscayne, FL: US Department of Commerce, National Oceanic and Atmospheric Administration, Pacific Marine Environmental Laboratory.

Mellinger, D. K., and Heimlich, S. L. (2013). Introduction to the special issue on methods for marine mammal passive acoustics. J. Acoust. Soc. Am. 134, 2381-2382. doi: 10.1121/1.4818149

Mellinger, D. K., Martin, S. W., Morrissey, R. P., Thomas, L., and Yosco, J. J. (2011). A method for detecting whistles, moans, and other frequency contour sounds. J. Acoust. Soc. Am. 129, 4055-4061. doi: 10.1121/1.3531926

Mellinger, D. K., Stafford, K. M., Moore, S., Dziak, R. P., and Matsumoto, H. (2007). Fixed passive acoustic observation methods for cetaceans. Oceanography 20:36. doi: 10.5670/oceanog.2007.03

Mellish, J.-A. E., Calkins, D. G., Christen, D. R., Horning, M., Rea, L. D., and Atkinson, S. K. (2006). Temporary captivity as a research tool: comprehensive study of wild pinnipeds under controlled conditions. Aquat. Mammals 32:58. doi: 10.1578/am.32.1.2006.58

Mellish, J.-A. E., Tuomi, P. A., and Horning, M. (2004). Assessment of ultrasound imaging as a noninvasive measure of blubber thickness in pinnipeds. J. Zoo Wildl. Med. 35, 116-118. doi: 10.1638/03-028

Mello, D. M. D., and Oliveira, C. A. (2016). Biological matrices for sampling free-ranging cetaceans and the implications of their use for reproductive endocrine monitoring. Mammal Rev. 46, 77-91. doi: 10.1111/mam. 12055

Miller, C. A., Best, P. B., Perryman, W. L., Baumgartner, M. F., and Moore, M. J. (2012a). Body shape changes associated with reproductive status, nutritive condition and growth in right whales Eubalaena glacialis and E. australi. Mar. Ecol. Prog. Ser. 459, 135-156. doi: 10.3354/meps09675

Miller, C. A., Reeb, D., Best, P. B., Knowlton, A. R., Brown, M. W., and Moore, M. J. (2011). Blubber thickness in right whales Eubalaena glacialis and Eubalaena australis related with reproduction, life history status and prey abundance. Mar. Ecol. Prog. Ser. 438, 267-283. doi: 10.3354/meps09174

Miller, P., Narazaki, T., Isojunno, S., Aoki, K., Smout, S., and Sato, K. (2016). Body density and diving gas volume of the northern bottlenose whale (Hyperoodon ampullatus). J. Exp. Biol. 219, 2458-2468. doi: 10.1242/jeb. 137349

Miller, P. J., Biuw, M., Watanabe, Y. Y., Thompson, D., and Fedak, M. A. (2012b). Sink fast and swim harder! Round-trip cost-of-transport for buoyant divers. J. Exp. Biol. 215, 3622-3630. doi: 10.1242/jeb.070128

Miller, P. J. O., Fedak, M., Lovell, P., Crocker, D. E., and Adachi, I. (2019). "On-board calculation and telemetry of the body condition of individual marine mammals", in Marine Mammal \& Biology Program Review, Book of Abstracts 23-26 April 2019 (Arlington, VA: Office of Naval Research).

Miller, P. J. O., Kvadsheim, P. H., Lam, F. P. A., Wensveen, P. J., Antunes, R., Alves, A. C., et al. (2012c). The severity of behavioral changes observed during experimental exposures of killer (Orcinus orca), long-finned pilot (Globicephala melas), and sperm (Physeter macrocephalus) whales to naval sonar. Aquat. Mammals 38, 362-401. doi: 10.1578/am.38.4.2012.362

Moore, M., Miller, C., Morss, M., Arthur, R., Lange, W., Prada, K., et al. (2001). Ultrasonic measurement of blubber thickness in right whales. J. Cetacean Res. Manage. (Special Issue) 2, 301-309.

Moretti, D. (2019). Determining the effect of Mid-Frequency Active (MFA) sonar on fitness of Blainville's beaked whales (Mesoplodon densirostris) in the Tongue of the Ocean. PhD Thesis, University of St. Andrews, St. Andrews.

Moretti, D., Thomas, L., Harwood, J., and Falcone, E. A. (2017). "A Population Consequence of Acoustic Disturbance Model for Cuvier's beaked whale (Ziphius cavirostris) in Southern California," in Marine Mammal \& Biology Program Review, Book of Abstracts 20-24 March 2017 (Arlington, VA: Office of Naval Research).

Moretti, D., Thomas, L., Marques, T., Harwood, J., Dilley, A., Neales, B., et al. (2014). A risk function for behavioral disruption of Blainville's beaked whales (Mesoplodon densirostris) from mid-frequency active sonar. PLoS One 9:e85064. doi: 10.1371/journal.pone.0085064
National Academies of Sciences Engineering, and Medicine (2017). Approaches to Understanding the Cumulative Effects of Stressors on Marine Mammals. Washington, DC: The National Academies Press.

National Research Council (2005). Marine Mammal Populations and Ocean Noise: Determining When Noise Causes Biologically Significant Effects. Washington, DC: National Academies Press.

Nelsons, T. M., Wallen, M. M., Bunce, M., Oskam, C. L., Lima, N., Clayton, L., et al. (2019). Detecting respiratory bacterial communities of wild dolphins: implications for animal health. Mar. Ecol. Prog. Ser. 622, 203-217. doi: 10.3354/ meps 13055

New, L. F., Clark, J. S., Costa, D. P., Fleishman, E., Hindell, M., Klanjšček, T., et al. (2014). Using short-term measures of behaviour to estimate long-term fitness of southern elephant seals. Mar. Ecol. Prog. Ser. 496, 99-108. doi: 10.3354/ meps10547

New, L. F., Harwood, J., Thomas, L., Donovan, C., Clark, J. S., Hastie, G., et al. (2013a). Modelling the biological significance of behavioural change in coastal bottlenose dolphins in response to disturbance. Funct. Ecol. 27, 314-322. doi: 10.1111/1365-2435.12052

New, L. F., Moretti, D. J., Hooker, S. K., Costa, D. P., and Simmons, S. E. (2013b). Using Energetic Models to Investigate the Survival and Reproduction of Beaked Whales (family Ziphiidae). PLoS ONE 8:e68725. doi: 10.1371/journal.pone. 0068725

Norman, S., Hobbs, R., Foster, J., Schroeder, J., and Townsend, F. (2004). A review of animal and human health concerns during capture-release, handling and tagging of odontocetes. J. Cetacean Res. Manage. 6, 53-62.

Nousek-McGregor, A. E., Miller, C. A., Moore, M. J., and Nowacek, D. P. (2013). Effects of body condition on buoyancy in endangered North Atlantic right whales. Physiol. Biochem. Zool. 87, 160-171. doi: 10.1086/ 671811

Page, B., Mckenzie, J., Hindell, M. A., and Goldsworthy, S. D. (2005). Drift dives by male New Zealand fur seals (Arctocephalus forsteri). Can. J. Zool. 83, 293-300. doi: 10.1139/z05-013

Palsbøll, P. J., Allen, J., Berube, M., Clapham, P. J., Feddersen, T. P., Hammond, P. S., et al. (1997). Genetic tagging of humpback whales. Nature 388, 767-769.

Patterson, T. A., McConnell, B. J., Fedak, M. A., Bravington, M. V., and Hindell, M. A. (2010). Using GPS data to evaluate the accuracy of state-space methods for correction of Argos satellite telemetry error. Ecology 91, 273-285. doi: 10.1890/08-1480.1

Peltier, H., Dabin, W., Daniel, P., Van Canneyt, O., Doremus, G., Huon, M., et al. (2012). The significance of stranding data as indicators of cetacean populations at sea: modelling the drift of cetacean carcasses. Eco. Indic. 18, 278-290. doi: 10.1371/journal.pone.0062180

Perrin, W. (1970). Color pattern of Eastern Pacific spotted porpoise Stenella graffmani Lonnberg (Cetacea, Delphinidae). Zool. N. Y. 54, 135-149.

Perrin, W. F., Coe, J. M., and Zweifel, J. R. (1976). Growth and reproduction of the spotted porpoise, Stenella attenuata, in the offshore eastern tropical Pacific. Fishery Bull. 74, 229-269.

Perryman, W. L., and Lynn, M. S. (1993). Identification of geographic forms of common dolphin (Delphinus delphis) from aerial photogrammetry. Mar. Mammal Sci. 9, 119-137. doi: 10.1111/j.1748-7692.1993.tb00438.x

Perryman, W. L., and Lynn, M. S. (2002). Evaluation of nutritive condition and reproductive status of migrating gray whales (Eschrichtius robustus) based on analysis of photogrammetric data. J. Cetacean Res. Manage. 4, 155-164.

Perryman, W. L., Reilly, S. B., and Rowlett, R. A. (2010). "Results of Surveys of Northbound Gray Whale Calves 2001-2009 and Examination of the Full Sixteen Years Series of Estimates From the Piedras Blancas Light Station. Cambridge: Rep. Intl. Whaling Commission, Scientific Committee.

Peterson, S. H., Lance, M. M., Jeffries, S. J., and Acevedo-Gutiérrez, A. (2012). Long distance movements and disjunct spatial use of harbor seals (Phoca vitulina) in the inland waters of the Pacific Northwest. PLoS ONE 7:e39046. doi: 10.1371/journal.pone.0039046

Pettis, H. M., Rolland, R. M., Hamilton, P. K., Brault, S., Knowlton, A. R., and Kraus, S. D. (2004). Visual health assessment of North Atlantic right whales (Eubalaena glacialis) using photographs. Can. J. Zool. 82, 8-19. doi: 10.1139/ z03-207

Piggott, M. P., and Taylor, A. C. (2003). Remote collection of animal DNA and its applications in conservation management and understanding the population 
biology of rare and cryptic species. Wildl. Res. 30, 1-13. doi: 10.1007/978-30348-6426-8_1

Pirotta, E., Booth, C. G., Costa, D. P., Fleishman, E., Kraus, S. D., Lusseau, D., et al. (2018). Understanding the population consequences of disturbance. Ecol. Evol. 8, 9934-9946.

Pirotta, E., Harwood, J., Thompson, P. M., New, L., Cheney, B., Arso, M., et al. (2015). Predicting the effects of human developments on individual dolphins to understand potential long-term population consequences. Proc. R. Soc. B 282:20152109. doi: 10.1098/rspb.2015. 2109

Pirotta, V., Smith, A., Ostrowski, M., Russell, D., Jonsen, I. D., Grech, A., et al. (2017). An economical custom-built drone for assessing whale health. Front. Mar. Sci. 4:425.

Pomeroy, P., O'connor, L., and Davies, P. (2015). Assessing use of and reaction to unmanned aerial systems in gray and harbor seals during breeding and molt in the UK 1. J. Unmann. Veh. Syst. 3, 102-113. doi: 10.1139/juvs-2015-0013

Ponganis, P. (2017). "Blood oxygen conservation in diving sea lions: how low does oxygen really go?," in Marine Mammal \& Biology Program Review, Dive Physiology Book of Abstracts 11 September 2017 (Arlington, VA: ONR MMB).

Ponganis, P., and McDonald, B. I. (2015). Deep-Diving California Sea Lions: Are they Pushing Their Physiological Limit? Arlington, VA: ONR MMB.

Postma, M., Bester, M. N., and De Bruyn, P. N. (2013). Spatial variation in female southern elephant seal mass change assessed by an accurate noninvasive photogrammetry method. Antarct. Sci. 25, 731-740. doi: 10.1017/ s0954102013000059

Reed, L., Mchugh, K., and Wells, R. S. (2015). "Post-Nuchal Depression as an Indicator of Health in Bottlenose Dolphins (Tursiops truncatus)," in 2015 Mote National Science Foundation REU (Sarasota, FL: Mote Marine Laboratory \& Aquarium)

Roletto, J. (1993). Hematology and serum chemistry values for clinically healthy and sick pinnipeds. J. Zoo Wildl. Med. 24, 145-157.

Rolland, R. M., Hamilton, P. K., Kraus, S. D., Davenport, B., Gillett, R. M., and Wasser, S. K. (2007). Faecal sampling using detection dogs to study reproduction and health in North Atlantic right whales (Euhalaena glacialis). J. Cetacean Res. Manage. 8:121.

Rolland, R. M., Schick, R. S., Pettis, H. M., Knowlton, A. R., Hamilton, P. K., Clark, J. S., et al. (2016). Health of North Atlantic right whales Eubalaena glacialis over three decades: from individual health to demographic and population health trends. Mar. Ecol. Prog. Ser. 542, 265-282. doi: 10.3354/meps 11547

Rosel, P., Mullin, K., Garrison, L., Schwacke, L., Adams, J., Balmer, B. C., et al. (2011). Photo-Identification Capture-Mark-Recapture Techniques For Estimating Abundance Of Bay, Sound And Estuary Populations Of Bottlenose Dolphins Along The U.S. East Coast And Gulf Of Mexico: A Workshop Report. Seattle, WA: NOAA Technical Memorandum NMFS-SEFSC-621.

Ross, P. S. (2000). Marine mammals as sentinels in ecological risk assessment. Hum. Ecol. Risk Assess. 6, 29-46. doi: 10.1080/108070300911 24437

Rosso, M., Ballardini, M., Moulins, A., and Wurtz, M. (2011). Natural markings of Cuvier's beaked whale Ziphius cavirostris in the Mediterranean Sea. Afr. J. Mar. Sci. 33, 45-57.

Schick, R. S., Kraus, S. D., Rolland, R. M., Knowlton, A. R., Hamilton, P. K., Pettis, H. M., et al. (2013a). Using hierarchical Bayes to understand movement, health, and survival in the endangered North Atlantic right whale. PLoS ONE 8:e64166. doi: 10.1371 /journal.pone. 0064166

Schick, R. S., New, L. F., Thomas, L., Costa, D. P., Hindell, M. A., Mcmahon, C. R., et al. (2013b). Estimating resource acquisition and at-sea body condition of a marine predator. J. Anim. Ecol. 82, 1300-1315. doi: 10.1111/1365-2656. 12102

Schorr, G. S., Falcone, E. A., and Rone, B. (2017). "Movements and diving behavior of beaked whales in Monterey Bay, CA: a comparative study site in the California Current Ecosystem," in Marine Mammal \& Biology Program Review, Book of Abstracts 20-24 March 2017 (Arlington, VA: Office of Naval Research).

Schwacke, L., and Wells, R. (2015). "The Bottlenose Dolphin (Tursiops truncatus) as a Model to Understand Variation in Stress and Reproductive Hormone Measures in Relation to Sampling Matrix, Demographics, and Environmental Factors". Arlington, VA: ONR MMB.
Schwacke, L. H., Smith, C. R., Townsend, F. I., Wells, R. S., Hart, L. B., Balmer, B. C., et al. (2013). Health of common bottlenose dolphins (Tursiops truncatus) in Barataria Bay, Louisiana, following the Deepwater Horizon oil spill. Environ. Sci. Technol. 48, 93-103.

Schwarz, L. K., Mchuron, E., Mangel, M., Wells, R. S., and Costa, D. P. (2016). "Stochastic dynamic programming: an approach for modelling the population consequences of disturbance due to lost foraging opportunities," in Proceedings of Meetings on Acoustics 4ENAL (London: ASA).

Sinclair, C., Sinclair, J., Zolman, E., Martinez, A., Balmer, B., and Barry, K. (2015). Remote Biopsy Sampling Field Procedures for Cetaceans Used During the Natural Resource Damage Assessment Of The Msc252 Deepwater Horizon Oil Spill. Seattle, WA: NOAA Technical Memorandum NMFS-SEFSC-nnn, 36.

Taylor, B. L., Martinez, M., Gerrodette, T., Barlow, J., and Hrovat, Y. N. (2007). Lessons from monitoring trends in abundance of marine mammals. Mar. Mammal Sci. 23, 157-175. doi: 10.1111/j.1748-7692.2006. 00092.x

Tershy, B. R., Breese, D., and Alvarez-Borrego, S. (1991). Increase in cetacean and seabird numbers in the Canal de Ballenas during an El Niño-Southern Oscillation event. Mar. Ecol. Prog. Ser. 69, 299-302. doi: 10.3354/meps069299

Thomas, L., Jaramillo-Legorreta, A., Cardenas-Hinojosa, G., NietoGarcia, E., Rojas-Bracho, L., Ver Hoef, J. M., et al. (2017). Last call: passive acoustic monitoring shows continued rapid decline of critically endangered vaquita. J. Acoust. Soc. Am. 142, EL512-EL517. doi: 10.1121/1. 5011673

Thompson, L. A., Spoon, T. R., Goertz, C. E., Hobbs, R. C., and Romano, T. A. (2014). Blow collection as a non-invasive method for measuring cortisol in the beluga (Delphinapterus leucas). PLoS ONE 9:e114062. doi: 10.1371/journal. pone. 0114062

Thompson, P. M., and Hammond, P. S. (1992). The use of photography to monitor dermal disease in wild bottlenose dolphins (Tursiops truncatus). Ambio 21, 135-137.

Thompson, P. M., and Harwood, J. (1990). Methods for estimating the population size of common seals, Phoca vitulina. J. Appl. Ecol. 27, 924-938.

Trego, M. L., Kellar, N. M., and Danil, K. (2013). Validation of blubber progesterone concentrations for pregnancy determination in three dolphin species and a porpoise. PLOS ONE 8:e69709. doi: 10.1371/journal.pone. 0069709

Trites, A. W., and Joy, R. (2005). Dietary analysis from fecal samples: how many scats are enough? J. Mammal. 86, 704-712. doi: 10.1644/1545-1542(2005) 086[0704:daffsh]2.0.co;2

Trumble, S. J., Robinson, E. M., Berman-Kowalewski, M., Potter, C. W., and Usenko, S. (2013). Blue whale earplug reveals lifetime contaminant exposure and hormone profiles. Proc. Natl. Acad. Sci. U.S.A. 110, 16922-16926. doi: 10.1073/pnas.1311418110

Unal, E., Goertz, C. E. C., Hobbs, R. C., Suydam, R., and Romano, T. (2018). Investigation of molecular biomarkers as potential indicators of health in wild belugas (Delphinapterus leucas). Mar. Biol. 165:19.

Van Bressem, M.-F., Van Waerebeek, K., Aznar, F. J., Raga, J. A., Jepson, P. D., Duignan, P., et al. (2009). Epidemiological pattern of tattoo skin disease: a potential general health indicator for cetaceans. Dis. Aquat. Organ. 85, 225-237. doi: $10.3354 /$ dao 02080

Vu, E. T., Clark, C., Catelani, K., Kellar, N. M., and Calambokidis, J. (2015). Seasonal blubber testosterone concentrations of male humpback whales (Megaptera novaeangliae). Mar. Mammal Sci. 31, 1258-1264. doi: 10.1111/ mms.12191

Wade, P. R., and Gerrodette, T. (1993). Estimates of Cetacean Abundance and Distribution in the Eastern Tropical Pacific. Ulsan: International Whaling Commission, 43.

Waite, J. N., Schrader, W. J., Mellish, J.-A. E., and Horning, M. (2007). Threedimensional photogrammetry as a tool for estimating morphometrics and body mass of Steller sea lions (Eumetopias jubatus). Can. J. Fish. Aquat. Sci. 64, 296-303. doi: 10.1139/f07-014

Webster, T., Dawson, S., and Slooten, E. (2010). A simple laser photogrammetry technique for measuring Hector's dolphins (Cephalorhynchus hectori) in the field. Mar. Mammal Sci. 26, 296-308. doi: 10.1111/j.1748-7692.2009.00326.x

Wells, R. S. (2014). "Social structure and life history of bottlenose dolphins near Sarasota Bay, Florida: insights from four decades and five generations," in 
Primates and Cetaceans, eds J. Yamagiwa and L. Karczmarski (Berlin: Springer), 149-172. doi: 10.1007/978-4-431-54523-1_8

Wells, R. S., Rhinehart, H. L., Hansen, L. J., Sweeney, J. C., Townsend, F. I., Stone, R., et al. (2004). Bottlenose dolphins as marine ecosystem sentinels: developing a health monitoring system. EcoHealth 1, 246-254.

Wells, R. S., and Scott, M. D. (1990). Estimating Bottlenose Dolphin Population Parameters from Individual Identification and Capture-Release Techniques. Ulsan: International Whaling Commission.

Wells, R. S., Smith, C. R., Sweeney, J. C., Townsend, F. I., Fauquier, D. A. Stone, R., et al. (2014). Fetal survival of common bottlenose dolphins (Tursiops truncatus) in Sarasota Bay, Florida. Aquat. Mammals 40:252. doi: 10.1578/am.40.3.2014.252

Wiig, Ø., Heide-Jørgensen, M., Lindqvist, C., Laidre, K., Postma, L., Dueck, L., et al. (2011). Recaptures of genotyped bowhead whales Balaena mysticetus in eastern Canada and West Greenland. Endangered Species Res. 14, 235-242. doi: $10.3354 /$ esr00365

Williams, T. (2015). High Risk Behaviors in Marine Mammals: Linking Behavioral Responses to Anthropogenic Disturbance to Biological Consequences. Arlington, VA: ONR MMB.

Wilson, B., Hammond, P. S., and Thompson, P. M. (1999). Estimating size and assessing trends in a coastal bottlenose dolphin population. Ecol. Appl. 9, 288-300. doi: 10.1890/1051-0761(1999)009[0288:esaati]2.0.co;2
Wilson, S. G., Taylor, J. G., and Pearce, A. F. (2001). The seasonal aggregation of whale sharks at Ningaloo Reef, Western Australia: currents, migrations and the El Nino/Southern Oscillation. Environ. Biol. Fishes 61, 1-11.

Yakovlev, Y. M., and Tyurneva, O. Y. (2005). A Note on Photo-Identification of the Western Gray Whale (Eschrictius robustus) on the Northeastern Sakhalin shelf, Russia, 2002-2004. Ulsan: International Whaling Commission Scientific Committee.

Zhelezniakov, A., Eerola, T., Koivuniemi, M., Auttila, M., Levänen, R., Niemi, M., et al. (2015). "Segmentation of saimaa ringed seals for identification purposes", in Proceedings of International Symposium on Advances in Visual Computing (ISVC), Las VegasISVC.

Conflict of Interest: The authors declare that the research was conducted in the absence of any commercial or financial relationships that could be construed as a potential conflict of interest.

Copyright (c) 2020 Booth, Sinclair and Harwood. This is an open-access article distributed under the terms of the Creative Commons Attribution License (CC BY). The use, distribution or reproduction in other forums is permitted, provided the original author(s) and the copyright owner(s) are credited and that the original publication in this journal is cited, in accordance with accepted academic practice. No use, distribution or reproduction is permitted which does not comply with these terms. 